\title{
Annonnaceae from Central-eastern Brazil
}

\author{
Paul J. M. Maas ${ }^{1}$ \\ Hiltje Maas-van de Kamer ${ }^{1}$ \\ Leo Junikka \\ Renato de Mello-Silva ${ }^{3}$ \\ Heimo Rainer ${ }^{4}$
}

\begin{abstract}
An annotated checklist of the Annonaceae from Central-Eastern Brazil, comprising the Distrito Federal and the States of Bahia, Espírito Santo, Goiás, Minas Gerais, Rio de Janeiro, São Paulo, and Tocantins is presented. Nineteen genera and 153 species are listed for this region. An identification key for genera, information about most recent revisions, short descriptions, notes on geographical distribution, and comments are provided.
\end{abstract}

Keywords: Annonaceae, Eastern and South-eastern Brazil, checklist

\section{RESUMO}

Uma listagem comentada das Annonaceae do centro-leste do Brasil, compreendendo o Distrito Federal e os Estados da Bahia, Espírito Santo, Goiás, Minas Gerais, Rio de Janeiro, São Paulo e Tocantins, é apresentada. Dezenove gêneros e 153 espécies de Annonaceae da região foram listados e comentados. São fornecidas chave de identificacão para os gêneros e informações sobre revisões recentes. São apresentadas descrições suscintas, distribuição geográfica e comentários para as espécies.

Palavras-chave: Annonaceae, Leste e Sudeste do Brasil, checklist

\section{INTRODUCTION}

Annonaceae is one of the largest Magnoliid families, with ca. 128 genera and 2300 species, mostly pantropical (Kessler, 1993). In Brazil, the Annonaceae comprise 26 genera (seven endemic) and ca. 260 species (Mello-Silva, personal communication), for the most part occurring in forests, with few representatives in open areas. The members of this family play a significant role in the composition of Brazilian vegetation and due to this they have been subject of great interest. Nevertheless, like many other Brazilian taxonomic groups, there is a scarcity of bibliografic references; many of them are not recent (e.g., the revisions of genera such as Annona, Guatteria, Unonopsis, and Xylopia by Robert E. Fries) and many are short publications (e.g., Berry \& Johnson, 1993; Dias \& Konoshita, 1998; Jansen-Jacobs ,1970; Johnson \& Mello-Silva ,1993; Johnson \& Murray, 1990; Maas, 1996, 1999; Maas \& Chatrou,1996; Maas et al., 1988, 1993; MelloSilva \& Pirani, 1988, 1994, 1999; Morawetz \& Maas, 1984; Záchia 1993; Záchia \& Irgang, 1996; van Zuilen \& Maas, 1994; see also Mennega, 1989, 1993), which complicate the access and interpretation of the data. On the

${ }^{1}$ National Herbarium of the Netherlands, Utrecht University Branch, Utrecht, The Netherlands.

${ }^{2}$ Department of Ecology and Systematics, Division of Systematic Biology, University of Helsinki, Finland.

${ }^{3}$ Instituto de Biociências, Universidade de São Paulo, São Paulo, SP, Brasil.

${ }^{4}$ Department of Systematics and Evolution of Higher Plants, University of Vienna, Austria. 
other hand, recent revisional studies for several genera (e.g., Anaxagorea, Bocagea, Cardiopetalum, Cymbopetalum, Duguetia, Hornschuchia, Rollinia, and Trigynaea) have contributed to up-date the systematics of Annonaceae.

In 1999, when Paul and Hiltje Maas and Leo Junikka were preparing for an Annonaceae field trip to the States of Rio de Janeiro and Espírito Santo, a preliminary list of Annonaceae species from Central-Eastern Brazil was prepared. The material collected during this trip comprised 11 genera and 25 species, six of which were undescribed, namely Annona (1), Ephedranthus (1), Pseudoxandra (1), Unonopsis (2), and Xylopia (1). The data of their collections were then incorporated in the list. This resulted in an annotated checklist of the Annonaceae of Central-Eastern Brazil, comprising the Distrito Federal (DF) and the States of Bahia (BA), Espírito Santo (ES), Goiás (GO), Minas Gerais (MG), Rio de Janeiro (RJ), São Paulo (SP), and Tocantins (TO). Nineteen genera and 153 species of Annonaceae from this region were recorded: Anaxagorea (2), Annona (28), Bocagea (3), Bocageopsis (1), Cardiopetalum (1), Cymbopetalum (1), Duguetia (20), Ephedranthus (4), Guatteria (41), Guatteriopsis (1), Hornschuchia (10),
Malmea (1), Oxandra (6), Porcelia (1), Pseudoxandra (2), Rollinia (13), Trigynaea (2), Unonopsis (6), and Xylopia (10). This checklist also includes recently published and unpublished data, such as taxonomic revisions of Annona and Oxandra, and floristic treatments (Guatteria from São Paulo; Annonaceae from Serra do Cipó).

The checklist includes an identification key to the genera, information about recent taxonomic revisions, a short description and the geographic distribution of each species, as well as comments on the relationships of some species.

\section{MATERIAL AND METHODS}

The description and geographical distribution of the species are based on collections deposited mainly in CEPEC, CVRD, GUA, H, MBML, R, RB, SPF, U, VIES, W, and WU (herbarium acronyms according to Holmgren et al., 1990). For each species one representative herbarium collection is cited and the distribution within C-E Brazil, based on data from herbarium labels and literature, is given. Many additional distributional data have been added by Mello-Silva.

References to literature are according to Stafleu \& Cowan (1976-1988) and Bridson \& Smith (1991).

\section{RESULTS}

\section{Key to the genera of Annonaceae from Central-Eastern Brazil}

1. Indument composed of stellate or scale-like hairs; fruit pseudosyncarpous, the basal carpels sterile and often forming a collar Duguetia 1. Indument composed of simple hairs or lacking (or rarely stellate hairs in Annona and Rollinia);

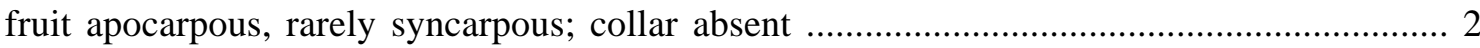

2. Flowers and fruit axillary; fruit apocarpous .............................................................. 3

2. Flowers and fruit terminal, leaf-opposed, or supra-axillary; fruit apocarpous or syncarpous

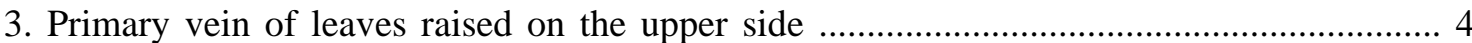

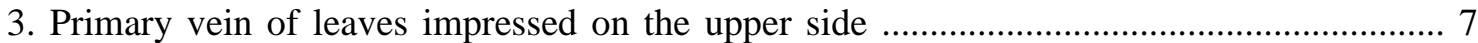

4. Marginal vein of leaves almost touching the margin; flowers whitish; monocarps 1-seeded Pseudoxandra

4. Marginal vein of leaves, when present, much further removed from margin; flowers green, white, cream to yellow or orange; monocarps 1-3-seeded 
5. Bracts several per flower; flowers white; monocarps 1-seeded

Oxandra

5. Bracts 2 per flower; flowers green, white, cream, yellow or orange; monocarps 1-3-seeded ...

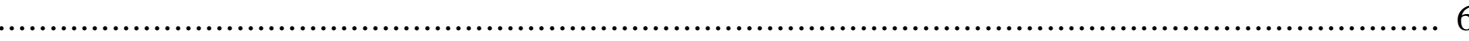

6. Leaves asymmetrical; flowers cream; monocarps 1-3, 2-3-seeded, sessile, seeds smooth

Bocageopsis

6. Leaves symmetrical (except $U$. riedeliana); flowers green, cream, yellow, or orange; monocarps 6-25, 1(-2)-seeded, distinctly stipitate, seeds pitted

Unonopsis

7. Petals often with a brownish indument of microscopical hairs; staminodes placed between stamens and carpels; monocarps explosively dehiscent, club-shaped, 2-seeded

Anaxagorea

7. Petals glabrous or with an indument visible to the naked eye; staminodes absent; monocarps indehiscent or not-explosively dehiscent, not club-shaped, 1-8-seeded

8. Bracts absent (T. axilliflora)

8. Bracts present 9

9. Leaves with secondary veins distinctly impressed on the upper side; flowers unisexual or bisexual Ephedranthus

9. Leaves with secondary veins inconspicuously impressed on the upper side; flowers bisexual ...

10. Bracts several per flower

Oxandra

10. Bracts 2 per flower

11. Pedicels with a basal articulation; petals unequal; monocarps 2-8-seeded, dehiscent

Xylopia

11. Pedicels with a suprabasal articulation; petals subequal; monocarps 1 -seeded, indehiscent .....

12. Inner petals imbricate

Guatteria

12. Inner petals valvate Guatteriopsis

13. Flowers dimerous (A. silvatica); monocarps explosively dehiscent, club-shaped

Anaxagorea

13. Flowers trimerous; monocarps indehiscent or not-explosively dehiscent, not club-shaped ...14

14. Bracts absent

14. Bracts present 20

15. Flowers pendent on 40-60 mm long pedicels, solitary; inner petals boat-shaped; monocarps many, 1-6-seeded, dehiscent, seeds with a large orange to red aril

Cymbopetalum

15. Flowers not pendent, on much shorter pedicels; inner petals not boat-shaped

16

16. Leaves asymmetrical; monocarps 2-3, 2-9 x 3-4 cm, thick-walled (wall 2.5-4 mm thick); inflorescences several-flowered, flowers yellow to cream, petals 4-5 times as long as sepals

Porcelia

16. Leaves symmetrical (base asymmetrical in some spp. of Hornschuchia); monocarps smaller, thin-walled (wall $<2 \mathrm{~mm}$ thick).

17. Leaves with 15-26 secondary veins, at almost right angles with the primary vein; petals basally connate, inner ones distinctly cordate

Cardiopetalum

17. Leaves with $<15$ secondary veins, generally at angles of $60-80^{\circ}$ with the primary vein; petals generally free, inner ones not cordate 18

18. Number of stamens $>40$; flower buds globose; monocarps 3-9 (T. oblongifolia)...Trigynaea 18. Number of stamens <20; flower buds globose or conical; monocarps 1-3 ....................... 19 19. Flower buds conical; petals linear, revolute; flowers solitary or in many-flowered inflorescences; inflorescences often flagelliform and produced from the main trunk (cauliflorous) .......Hornschuchia 19. Flowers buds globose; petals ovate to elliptic, not revolute; flowers solitary Bocagea 
20. Outer petals winged; flowers propellor-like; fruit syncarpous, rarely apocarpous ...... Rollinia 20. Outer petals not winged; flowers never propellor-like; fruit syncarpous or apocarpous ...... 21

21. Fruit syncarpous, of many, connate carpels; petals generally thick $(>1 \mathrm{~mm})$............. Annona 21. Fruit apocarpous, of many, stipitate, 1 -seeded monocarps; petals thin $(<1 \mathrm{~mm})$........ Malmea

\section{Descriptions}

\section{AnAXagorea A.F.C.P. de Saint-Hilaire}

Leaves with impressed primary vein on the upper side; indument of microscopical, simple to stellate hairs; bracts 2 per flower; flowers solitary, axillary or terminal, trimerous, rarely dimerous, sepals free, petals free, thick, often yellow to cream, with a brownish indument; fruit apocarpous, monocarps 10-20, club-shaped, 2-seeded, explosively dehiscent.

Maas, P. J. M. \& Westra, L. Y. Th. 1984-1985. Studies in Annonaceae II. A monograph of the genus Anaxagorea A.St.-Hil. Bot. Jahrb. Syst. 105: 73-134. 1984; 105: 145-204. 1985.

1. Anaxagorea dolichocarpa Sprague \& Sandwith, Bull. Misc. Inform. 1930: 475. 1930. Bahia (Ilhéus, Itacaré, Lençóis, Maraú, Olivença, Palmeiras, Una), Espírito Santo (Linhares, Santa Cruz), Goiás (Serra Dourada), Minas Gerais (Carangola, Marliéria, Muriaé), Rio de Janeiro (Nova Friburgo, Parati, Rio das Ostras, Rio de Janeiro), São Paulo (Ubatuba). From sea level to $1000 \mathrm{~m}$. Forest.

Tree, up to $15 \mathrm{~m}$ tall; leaves narrowly elliptic to narrowly obovate, $9-45 \times 3-16 \mathrm{~cm}$; flowers axillary, cream to yellow.

Harley et al. 17549 (K, U).

2. Anaxagorea silvatica R.E. Fries, Acta Horti Berg. 12(1): 10. 1934.

Espírito Santo (Santa Teresa), Minas Gerais (Viçosa). To $750 \mathrm{~m}$. Forest.

Tree, 5-8 m tall; leaves narrowly obovate to narrowly elliptic, $13-19 \times 2-6 \mathrm{~cm}$; flowers terminal, dimerous or trimerous; petals white to cream, ciliate.

Unique in CE Brazil by dimerous flowers. This species has a leaf-opposed or terminal inflorescence (rarely found in $A$. dolichocarpa).
Local name: Pindaíba.

Maas et al. 8836 (MBML, U).

\section{Annona Linnaeus (by H. Rainer)}

Leaves with impressed primary vein on the upper side; indument of simple (to stellate) hairs; bracts 2 per flower; flowers solitary or in few- to many-flowered, terminal, leafopposed, or infra-axillary inflorescences, sepals connate or free, petals free, sometimes connate at the base, often thick and fleshy, white, yellow, rarely orange or red; fruit syncarpous composed of many carpels, many-seeded.

Fries, R.E. 1931. Revision der Arten einiger Anonaceen-Gattungen II. Acta Horti Berg. 10(2): 197-341.

1. Annona acutiflora Martius in Martius, Fl. bras. 13(1): 10. 1841.

Bahia (Salvador), Espírito Santo (Conceição da Barra, Santa Teresa, Vitória), Rio de Janeiro (Cabo Frio, Rio de Janeiro). At sea level. Restinga (coastal thickets).

Tree, 2-6 $\mathrm{m}$ tall; leaves narrowly elliptic, 5-17 x 2-7 cm; flowers red, outer petals connate at the base, inner petals much smaller and adnate to outer petals; fruit ovoid to narrowly ovoid, seeds brown.

Folli 1414 (CVRD, U).

2. Annona aurantiaca Barbosa Rodrigues, Pl. Mattogr. 5. t. 3. 1898.

Goiás (Campos Belos), Tocantins (Arraias, Paranã). At 450-700 m. Cerrado or cerradão.

Tree, 2-5 m tall; leaves (sub)coriaceous, elliptic, 3-15 x 2-7 cm, margins parallel, base conspicuously cordate almost stem-clasping, apex obtuse to emarginate; flowers terminal, 
pendent, outer petals orange; fruit small, hairy, obovate to globose, slightly muricate.

Weddell $3064(\mathrm{P})$.

\section{Annona burchellii R.E. Fries, Acta Horti}

Berg. 10(2): 232.t. 12. 1931.

Goiás (Cavalcante). At $750 \mathrm{~m}$. Cerrado.

Shrub or tree, $1.5-2 \mathrm{~m}$ tall; leaves elliptic, 4-7 x 2-5 cm, margins often parallel, densely hairy on the lower side; flowers white, solitary, terminal or internodal; fruit ovoid.

Irwin et al. 34800 (NY, U).

4. Annona cacans Warming, Vidensk. Meddel. Dawsk Naturalist. Foren. Kjøbenhavn 1873: 155. 1873.

Bahia (Castro Alves), Espírito Santo (Linhares, Santa Teresa), Minas Gerais (Alto Caparaó, Araguari, Carangola, Lagoa Santa), Rio de Janeiro (Nova Friburgo, Petrópolis, Rio das Ostras), São Paulo (Moji-Guaçu, Pindorama). At sea level to $1500 \mathrm{~m}$. Coastal premontane to montane rain forest (Mata Atlântica).

Tree, 10-30 m tall; leaves narrowly elliptic, acuminate, $4-30 \times 1.5-7 \mathrm{~cm}$, glabrous on both sides; flowers reddish, to $10 \mathrm{~mm}$ in diam., outer petals partly connate, inner petals much smaller and adnate to outer petals; fruit green, glaucous, almost without areoles.

Peixoto 3181 (U).

5. Annona cherimola Miller, Gard. Dict. ed. 8. nr. 5. 1768.

Cultivated; Minas Gerais (Belo Horizonte). At 150-2600 m. Originally growing in dry forests, along streams.

Tree, 2-10 m tall; leaves obovate, 5-25 x 3-14 cm, hairy on both sides, particularly on the lower side; flowers whitish, in few- to many-flowered rhipidia, outer petals elongate, triquetrous, outer side covered with appressed hairs, inner base red, inner petals absent; fruit with usually sunken areoles, seeds brownish-black.

$$
\text { Barreto } 909 \text { (U). }
$$

6. Annona coriacea Martius in Martius, Fl. bras. 13(1): 6. t. 1. 1841.

Bahia (Abaíra, Caetité, Correntina, Jacobina, Lençóis, Mucujê, Palmeiras, Piatã, Rio de Contas), Goiás (Caiapônia, Caldas Novas, Colinas do Sul, Cristalina, Niquelândia, Santa Teresa, São João da Aliança, Uruaçu), Minas Gerais (Berilo, Cristália, Delfinópolis, Francisco Sá, Grão-Mogol, Januária, Paracatu, Perdizes, Uberlândia), São Paulo (Altinópolis, Avanhandava, Bauru, Botacatu, Casa Branca, Cerqueira César, Corumbataí, Itirapina, Luiz Antônio, Moji-Guaçu, Piraçununga, Suzanópolis, Votuporanga), Tocantins (Brejinho de Nazaré). At 80-1120 m. Very common in savannas.

Shrub or tree, 3-18 m tall; leaves coriaceous, broadly elliptic, 6-21 x 5-14 cm, glabrous on both sides, base often cordate and almost stem-clasping, margin often undulate; flowers orange to pinkish-orange, solitary, terminal, petals thick and fleshy, inner petals imbricate; fruit large (to $1.5 \mathrm{~kg}$ ), without areoles, hirsute, becoming glabrous at maturity.

Paula 176 (SP).

7 Annona cornifolia A.F.C.P. de Saint-Hilaire, Fl. Bras. merid. 1: 33. 1825.

Goiás (Cabeceiras), Minas Gerais (Januária, Joaquim Felício, Montes Claros, Unaí), São Paulo (Aguas de Santa Bárbara, Botucatu, Icém, Igaçaba, Itaí, Itapeva, Itararé, Jales, Magda, Piraçununga). At 110-1000 m. Wooded islands in cerrado and border of savanna woodland (cerrado, cerradão).

Shrub or tree, 0.5-6 m tall; leaves ovate to obovate, $4-12 \times 2-8 \mathrm{~cm}$, hairy on both sides, sculptured on the lower side; flowers white, inner petals adnate to outer petals; fruit green, maturing orange, globose to obpyriform, areolate.

Irwin et al. 23793 (NY).

8. Annona crassiflora Martius in Martius, Fl. bras. 13(1): 7. t. 2. 1841.

Bahia (Barreiras, Correntina), Distrito Federal (Brasília, Samambaia), Goiás 
(Caiapônia), Minas Gerais (Formiga, GrãoMogol, Jaboticatubas, Januária, Joaquim Felício, Lagoa Santa, Paracatu, Santana do Riacho, Uberlândia, Unaí), São Paulo (Altinópolis, Anhembi, Botucatu, Itatinga, Itirapina, Moji-Guaçu, São Carlos), Tocantins (Aurora do Norte). At 400-1200 m. Cerrado or cerradão.

Small tree, of unknown height; stem often with tortuous, bark thick, corky, fissured; leaves ovate to obovate, $6-17 \times 3-12 \mathrm{~cm}$, glabrous, glaucous; flowers white, on leafless branches, outer petals conspicuously thickened towards the apex, outer side ferruginous hairy, inner petals laterally adnate to outer petals, much smaller; fruit globose, woody, areoles pronouncedly elevated.

Plowman et al. 8149 (U).

9. Annona crotonifolia Martius in Martius, Fl. bras. 13(1): 46. 1841.

Bahia (Formosa do Rio Preto), Goiás (Caiapônia), Minas Gerais (Lagoa Santa), São Paulo (Itu). At 500-1000 m. Cerrado or cerradão.

Shrub, 0.4-1.5 m tall, single-stemmed to slightly branched; leaves narrowly elliptic, 6-15 x $2-5.5 \mathrm{~cm}$, acute at the base and the apex, strongly hairy on both sides, venation strongly protruding on the lower side; flowers terminal or leaf-opposed, pendent, outer petals broadly triangular, acute, inner petals narrowly elongate-ovate; fruit ovoid, slightly muricate.

Mendonça et al. 2863 (U).

10. Annona dioica A.F.C.P. de Saint-Hilaire, Fl. Bras. merid. 1: 34.1825.

Goiás (Brasilândia, Cabeceiras), Minas Gerais (Itutinga, Paracatu, Uberlândia), São Paulo (Águas de Santa Bárbara, Assis, Itapetininga, Itararé, Itirapina, Leme, Mococa, Paulo de Faria, Piraçununga, Santa Rita do Passa Quatro, São Carlos, Votuporanga). At 80-1000 m. Cerrado.

Small shrub, single-stemmed to moderately branched, $0.5-2 \mathrm{~m}$ tall; leaves broadly ovate to obovate, $5-16 \times 3-15 \mathrm{~cm}$, ascending, base rounded to slightly cordate, apex obtuse, pronouncedly hairy (strigose) on both sides; flowers terminal or leaf-opposed; fruit muricate.

Ratter et al. 5078 (E).

11. Annona gardneri R.E. Fries, Acta Horti Berg. 10(2): 211. 1931.

Bahia (Formosa do Rio Preto). Cerrado and cerrado-campo rupestre transition.

Shrub, to $1.5 \mathrm{~m}$ tall; leaves coriaceous, elliptic to narrowly ovate, 3-6 x 2-4 cm, sessile, glabrous; flowers white, terminal; fruit ovoid, areolate, muricate.

This is a doubtful taxon, only known from 2 collections.

Walter 2947 (CEN, SPF).

12. Annona glabra Linnaeus, Sp. pl. 537. 1753.

Bahia (Ilhéus, Imbassaí, Nova Viçosa), Espírito Santo (Linhares, Lagoa de Itapamerim), Minas Gerais (Marliéria), Rio de Janeiro (Magé, Muriqui), São Paulo (Bertioga, Cananéia, Iguape, Itanhaém, Ubatuba) At sea level. Vegetation behind mangroves.

Tree, 2-15 m tall; leaves subcoriaceous, elliptic, 6-25 x 2.5-9 cm, glabrous, glaucous; flowers white, usually solitary, inner petals valvate, base with deep red patch; fruit yellow at maturity, obovoid, seeds with a prominent rim, floating.

Folli 471 (CVRD, U).

13. Annona impressivenia Safford ex R.E. Fries, Acta Horti Berg. 10(2): 223. 1931.

Rio de Janeiro (São Gonçalo). At 50-750 $\mathrm{m}$. Mixed restinga.

Tree, of unknown height; leaves coriaceous, narrowly obovate, acuminate, 8-16 $x$ 3-6 cm, secondary veins impressed on the lower side; flowers leaf-opposed, sepals connate, outer petals ovate-triangular, acute; fruit unknown.

This is a doubtful taxon, the type collection is of poor quality and of uncertain provenance.

Glaziou 17464 (B). 
14. Annona malmeana R.E. Fries, Kongl. Svenska Vetenskapsakad. Handl. n.s. 34(5): 44. t. 4, f. 1 \& 2. 1900.

Bahia (São Desidério), Goiás (Cristalina, Niquelândia), Minas Gerais (Itacambira, Paracatu), São Paulo (Morumbi). At 500-1200 m. Cerrado or cerradão.

Shrub, $1.5-3 \mathrm{~m}$ tall; leaves broadly ovate to obovate, $4-18 \times 2.5-11 \mathrm{~cm}$, glabrous and waxy (bluish when dry) on the upper side, strongly tomentose on the lower side; flowers white, outer petals broadly triangular; fruit ovate, slightly muricate, hairy.

This species is possibly of hybrid origin with A. coriacea and A. tomentosa as parent species.

Irwin et al. 13749 (NY).

15. Annona montana Macfadyen, Fl. Jamaica 1: 7.1837.

Bahia (Porto Seguro), Goiás (Barro Alto, Caiapônia, Campinaçu, Colinas do Sul, Minaçu), Minas Gerais (Águas de Contendas), São Paulo (Pariquera-Açu, São Paulo). At 40-900 m. Forest.

Tree, 2.5-15 m tall; leaves (narrowly) elliptic, margins often characteristically parallel, 5-30 x 3-12 cm, apex acuminate, extreme tip obtuse (without mucro), domatia present in the axils of the midrib and secondary veins on the lower side; flowers whitish-yellow, outer petals broadly triangular; fruit globose to ovoid, protuberances weak, easily breaking off when touched, areoles significantly delimited by brown lines.

Mori et al. 9765 (NY).

16. Annona monticola Martius in Martius, Fl. bras. 13(1): 7. 1841.

Distrito Federal (Brasília), Goiás (Caiapônia, Campinaçu, Cristalina, São João da Aliança), Minas Gerais (Belo Horizonte, Brumadinho, Datas, Diamantina, Gouveia, Itacambira, Joaquim Felício, Nova Lima, Paracatu, Santana do Riacho, Vespasiano). At 500-1250 m. Cerrado or cerradão.

Shrub, 0.5-2 m tall, all parts strongly tomentose; leaves coriaceous, broadly elliptic, 9-25 x 4-15 cm, ascending; flowers large, nodding, inner petals imbricate; fruit muricate, protuberances like hooks.

Irwin et al. 26009 (NY).

17. Annona muricata Linnaeus, Sp. pl. 536. 1753.

Cultivated throughout the area, in the lowland. Bahia (Ilhéus), Minas Gerais (Curvelo).

Small tree, to $10(-15) \mathrm{m}$ tall; leaves narrowly obovate to elliptic, 6-22 x 2-9 cm, apex acuminate, tip with a short mucro, small domatia present in the axils of the midrib and secondary veins on the lower side; flowers whitish-yellow, outer petals with a prominently elongate tip; fruit green, irregularly ovoid, protuberances prominent, massive.

Local name: Graviola.

Burchell 9587 (K).

18. Annona reticulata Linnaeus, Sp. pl. 537. 1753.

Cultivated throughout the area. In the lowland. Bahia (Salvador), São Paulo (São Paulo).

Small tree, to $12 \mathrm{~m}$ tall, similar to $A$. squamosa; leaves chartaceous, narrowly elliptic, 5-27 x 2-8 cm, glabrous; flowers in few-flowered rhipidia, greenish-white, outer petals with a red inner base, inner petals absent; fruit areolate, areoles flat.

Local name: Condessa.

Simonis \& Carlos 246 (U).

19. Annona saffordiana R.E. Fries, Acta Horti Berg. 10(2): 272. 1931.

Minas Gerais (Sabará). Cerrado and cerrado-campo rupestre transition.

Shrub, to $2 \mathrm{~m}$ tall, young parts fuscous tomentose; leaves elliptic to obovate, $4-8 \mathrm{x}$ $1.5-5 \mathrm{~cm}$; flowers leaf-opposed, outer petals connate, inner petals much smaller; fruit unknown.

Only known from 3 collections.

Glaziou 18839 (holotype, B; isotype, R). 
20. Annona salzmannii A. de Candolle, Mem. Soc. Phys. Genève 5: 197. 1832.

Bahia (Ilhéus, Itanagra, Porto Seguro, Salvador, Una). At sea level to $100 \mathrm{~m}$. Coastal rain forest (Mata Atlântica).

Tree, 6-20 m tall; leaves coriaceous, obovate to broadly obovate, often emarginate at the apex, secondary veins impressed on the lower side; flowers yellowish, sepals connate, forming a cup, petals free, triangular, inner petals valvate; fruit globose, slightly areolate and muricate.

Thomas et al. 8913 (NY).

21. Annona spinescens Martius in Spix \& Martius, Reise in Brasilien 2: 555. 1828.

Bahia (Barra, Carnaúba Grande, Juazeiro, Maracás, Morpará, Xique-Xique). At ca. 300 m. Caatinga.

Shrub or tree, 2-4 m tall, branches spiny; leaves elliptic, $1.5-6 \times 1-3 \mathrm{~cm}$, base slightly decurrent, apex obtuse, papillose on the lower side; flowers white, nodding, outer petals connate, pedicels woody; fruit ovoid, seeds black.

Davidse \& D'Arcy 12007 (MO).

22. Annona squamosa Linnaeus, Sp. pl. 537. 1753.

Cultivated throughout the area. In the lowland. São Paulo (Mirandópolis).

Tree, 2-6 m tall; leaves thin, ovate to elliptic, 3-20 x 1.5-8 cm, secondary venation distant, slightly hairy on the lower side; flowers cream, outer petals elongate, thick, triquetrous, red at the inner base; fruit globose to ovoid, with elevated (baccate) areoles, seeds black.

Local name: Ata, Fruta-do-conde.

Ginzberger \& Zerny s.n. [1927] (WU).

23. Annona tomentosa R.E. Fries, Ark. Bot. 5(4): 18. t. 3, f. 5-7. 1906.

Bahia (Correntina, Rio das Contas), Distrito Federal (Brasília, Samambaia), Espírito Santo (Vargem), Goiás (Água Fria, Alto Paraíso de Goiás, Caldas Novas, Campinaçu, Cristalina, Goiânia, Ipameri, Minaçu, Niquelândia,
Uruaçu), Minas Gerais (Botumirim, Diamantina, Grão-Mogol, Itacambira, Januária, Joaquim Felício, Laoa Santa, Perdizes, Presidente Juscelino, Santana do Riacho, São João d'El Rei, São Tomé das Letras, Tiradentes, Uberlândia), São Paulo (Itu). At 300-1150 m. Cerrado or cerradão.

Small shrub, 0.8-2 m tall, single-stemmed to moderately branched; leaves narrowly to broadly elliptic, 5-24 x 3-12 cm, base acute to obtuse, hairy on both sides; flowers terminal or leaf-opposed, pendent, outer petals broadly triangular, acute, inner petals narrowly ovate; fruit ovoid, hairy, muricate.

Violatti et al. $27(\mathrm{U})$.

24. Annona vepretorum Martius in Martius, Fl. bras. 13(1): 16. 1841.

Bahia (Abaíra, Brumado, Livramento do Brumado, Mucujê, Nazaré, Rio de Contas, Rio do Antônio, Santa Luz). At 300-750 m. Caatinga.

Shrub or tree, 2.5-10 m tall, stem often branched from the base and tortuous; leaves broadly elliptic, $2-7 \times 1.5-4 \mathrm{~cm}$, apex obtuse; flowers white, solitary or paired, nodding, outer and inner petals free, inner petals valvate; fruit globose, thick-walled, seeds black.

Harley et al. 27128 (CEPEC, K, SPF, U).

25. Annona warmingiana Mello-Silva \& Pirani, Kew Bull. 54(1): 237. 1998.

Annona pygmaea (Warming) Warming, non W. Bartram

Distrito Federal (Brasília, Samambaia), Goiás (Caiapônia), Minas Gerais (Brumadinho, Caldas, Lagoa Santa, Santana do Riacho, São Roque de Minas). At 800-1250 m. Cerrado.

Unbranched to few-branched dwarf shrub, 0.1-0.5 m tall, with a subterranean woody stem (xylopodium); leaves narrowly elliptic, 3.5-12 x 1.5-6 cm; flowers terminal, outer side of outer petals "golden"-tomentose, inner petals imbricate; fruit globose.

Irwin \& Soderstrom 7551 (NY). 
26. Annona sp. nov. 1

Bahia (Prado). At sea level. Restinga.

Shrub, $2 \mathrm{~m}$ tall; leaves coriaceous, broadly elliptic, $12-22$ × 6-11 cm, glabrous, apex shortly acuminate; flowers not seen; fruit immature, areolate, muricate.

Only once collected.

Thomas et al. 9974 (NY).

\section{Annona sp. nov. 2}

Bahia (Jequié). Campo rupestre or caatinga.

Shrub, $2.5 \mathrm{~m}$ tall; leaves, broadly elliptic to circular, $10-16 \times 8-10 \mathrm{~cm}$, apex shortly acuminate, glabrous on the upper side, densely tomentose on the lower side; flower buds globose, calyx enlarged, outer side of outer petals tomentose; fruit unknown.

Only once collected.

Mori et al. 11191 (NY).

\section{Annona sp. nov. 3}

Espírito Santo (Linhares). At sea level. Forest on white sand.

Shrub or treelet, 1-4 m tall; leaves narrowly obovate, 9-14 x 3.5-5 cm, glabrous on the upper side, golden brown tomentose on the lower side; flowers orange, leaf-opposed, outer side of outer petals densely golden tomentose, apex recurved, inner petals imbricate; fruit unknown.

Maas et al. 8830 (CVRD, U).

\section{Bocagea A.F.C.P. de Saint-Hilaire}

Leaves with slightly raised to impressed primary vein on the upper side; indument of simple hairs; bracts absent; flowers supraaxillary, solitary, sepals basally connate into a saucer-shaped calyx or free, petals free, whitish; fruit apocarpous, monocarps 1-3, globose to obovoid, 2-5-seeded.

Johnson, D.M. \& Murray, N.A. 1995. Synopsis of the tribe Bocageeae (Annonaceae) with revisions of Cardiopetalum, Froesiodendron, Trigynaea, Bocagea, and Hornschuchia. Brittonia 47(3): 248-319.
1. Bocagea longepedunculata Martius in Martius, Fl. bras. 13(1): 45. 1841.

Bahia (Porto Seguro), Espírito Santo (Linhares), Minas Gerais (Ataléia, Frei Gaspar). At sea level. Forest.

Shrub, 3-4 m tall; leaves narrowly obovate to narrowly elliptic, $12-16 \times 3.5-5 \mathrm{~cm}$, primary vein impressed on the upper side; flowers yellow, petals to $6.5 \mathrm{~mm}$ long, pedicels slender, 15-50 mm long; fruit unknown.

This species is very rare and known from just a few collections.

Magalhães 18868 (RB, U).

2. Bocagea viridis A.F.C.P. de Saint-Hilaire, Fl. Bras. merid. 1: 42. t. 9. 1825.

Espírito Santo (Vitória), Rio de Janeiro (Duque de Caxias, Miguel Pereira, Parati). Forest.

Shrub or treelet, 2-5 m tall; leaves narrowly ovate to ovate, $7-8.5 \times 2-4 \mathrm{~cm}$, primary vein plane or slightly impressed on the upper side; flowers white, ca. $4 \mathrm{~mm}$ long, pedicels slender, 5-7 $\mathrm{mm}$ long, sepals free; monocarps 1-3, ca. $6 \mathrm{~mm}$ long, obovoid, tuberculate, seeds unknown.

This species is very rare and known from just three collections. The type locality, Ubá, is nowadays a district of the Municipality of Miguel Pereira.

Kuhlmann 480 (RB).

\section{Bocagea sp.}

São Paulo (Cubatão). Forest.

Tree, $6 \mathrm{~m}$ tall; leaves narrowly elliptic, occasionally narrowly obovate, 9-10 x 3-3.5 $\mathrm{cm}$, primary vein slightly raised to slightly impressed on the upper side; flowers white, petals $3 \mathrm{~mm}$ long, pedicels slender, ca. $3 \mathrm{~mm}$ long; young monocarp 1, ovoid-ellipsoid, $4.5 \mathrm{x}$ $3.9 \mathrm{~mm}$, seeds 4-5.

Only once collected.

Benko-Iseppon 1 (OWU, SPF).

\section{Bocageopsis R.E. Fries}

Leaves asymmetrical, with raised primary vein on the upper side; indument of simple 
hairs; bracts 2 per flower; inflorescences axillary, many-flowered, sepals slightly connate at the base, petals free, cream; fruit apocarpous, monocarps 1-3, indehiscent, 2-3seeded.

Fries, R.E. 1931. Revision der Arten einiger Anonaceen-Gattungen II. Acta Horti Berg. 10(2): 143-148.

1. Bocageopsis mattogrossensis (Martius) R.E. Fries, Acta Horti Berg. 10(2): 147. f. 2 b. 1931.

Goiás (Doverlândia, Mineiros, Rio Verde, Serranópolis). To $700 \mathrm{~m}$. Primary, gallery, or secondary forest.

Tree, 4-22 m tall; leaves asymmetrical, narrowly elliptic, 10-12 x 3-4 cm, rather densely covered with appressed hairs and papillate on the lower side; petals 3-5 mm long; monocarps green to yellow-orange, maturing black when ripe, glaucous, subglobose, 5-10 $\mathrm{mm}$ in diam., stipes absent.

Ratter et al. 7372 (E, U).

\section{Cardiopetalum Schlechtendal}

Leaves with 15-26 prominent secondary veins, primary vein flat to slightly raised on the upper side; indument of simple hairs; bracts absent; flowers solitary, internodal, supraaxillary, or terminal with an opposing aborted leaf, sepals basally connate, petals basally connate, whitish, short-clawed, inner ones cordate; fruit apocarpous, monocarps 1-15, dehiscent, 1-10-seeded, seeds arillate.

Johnson, D.M. \& Murray, N.A. 1995. Synopsis of the tribe Bocageeae (Annonaceae) with revisions of Cardiopetalum, Froesiodendron, Trigynaea, Bocagea, and Hornschuchia. Brittonia 47(3): 248-319.

1.Cardiopetalum calophyllum Schlechtendal, Linnaea 9: 328. 1835.

Distrito Federal (Brasília), Goiás (Alto Paraíso de Goiás, Caldas Novas, Campinaçu, Cristalina, Minaçu, Pirenópolis, São João da
Aliança), Minas Gerais (Araguari, Ituiutatu, Paracatu, São Simão, Três Marias, Uberlândia, Unaí). To $1200 \mathrm{~m}$. Mostly in cerrados and transitions to gallery forest.

Tree or shrub, 1.5-12 m tall; leaves often narrowly elliptic, 5-16 x 2-6 cm; flowers yellow, cream, or white; monocarps constricted and more or less falciform, 8-35 x 7-10 mm, seeds with yellowish white aril.

This species is typical by its many secondary veins and connate petals.

Thomas et al. 4302 (NY, U).

\section{Cymbopetalum Bentham}

Leaves with primary vein raised on the upper side; indument of simple hairs; bracts absent; flowers solitary, pendent on elongate pedicels, internodal or leaf-opposed, sepals connate at the base, petals free, yellowish to cream, strongly unequal, the inner ones boatshaped; fruit apocarpous, monocarps 5-25, dehiscent, 1-6-seeded, seeds with large aril.

Murray, N.A. 1993. Revision of Cymbopetalum and Porcelia (Annonaceae). Syst. Bot. Monogr. 40: 1-121.

1. Cymbopetalum brasiliense (Velloso) Bentham ex Baillon, Hist. Pl. 1: 240. 1868.

Bahia (Gandu, Ilhéus, Itabuna, Juçari, Porto Seguro, Santa Cruz Cabrália, Una), Espírito Santo (Linhares), Minas Gerais (Marliéria). To $250 \mathrm{~m}$. Forest.

Treelet, 1-5 m tall; leaves elliptic to obovate, $15-27$ x 6-11 cm; flowers pendent on 40-60 $\mathrm{mm}$ long pedicels, inner petals boat-shaped; monocarps constricted, 8-40 x 9-15 mm, seeds with large orange to red aril.

Santos \& Silva 3301 (CEPEC, U).

VII. Duguetia A.F.C.P. de Saint-Hilaire

Leaves with impressed, rarely with flat to slightly raised primary vein on the upper side; indument of stellate or scale-like hairs; bracts 2 per flower; flowers solitary or in few- to several-flowered inflorescences, leaf-opposed, 
supra-axillary, subaxillary, or rarely terminal, sepals free to slightly connate, petals free, generally cream, sometimes yellow or red; fruit pseudosyncarpous, composed of 10-350 free to connate monocarps, the basal carpels sterile and mostly forming a distinct collar.

Maas, P.J.M., Westra, L.Y.Th., and Chatrou, L.W. Duguetia. Flora Neotropica Monograph. In press.

1.Duguetia bahiensis Maas, Bot. Jahrb. Syst. 115: 83. 1993.

Bahia (between Eunápolis and Tatela, Ilhéus, Itabuna, Itambé, Maraú, Uruçuca). At sea level. Coastal rain forest.

Tree, 4-10 $\mathrm{m}$ tall; leaves narrowly elliptic, $15-35 \times 5-11 \mathrm{~cm}$, sparsely covered with stellate scales on the lower side, primary vein impressed on the upper side; flowers cream to yellow; fruit 25-35 mm in diam., carpels 25-45.

Maas et al. 6987 (CEPEC, LPZ, MO, U).

2. Duguetia chrysocarpa Maas, Bot. Jahrb. Syst. 121: 471. f. 6-8. 1999.

Bahia (Belmonte, Una), Espírito Santo (Alto Limoeiro, Linhares), Minas Gerais (Caratinga, Muriaé). At 0-400 m. Forest.

Tree or shrub, 3-10 m tall; leaves narrowly elliptic, $12-25 \times 4-8 \mathrm{~cm}$, densely to sparsely covered with stellate hairs on the lower side, primary vein impressed on the upper side; flowers cream to yellow; fruit $30 \times 35 \mathrm{~mm}$, carpels ca. 50.

Local name: Pindaíba-da-mata.

This species has a fruit with a typical golden-brown indument; it has been confused with $D$. bahiensis, from which it differs in a leaf indument of stellate hairs instead of stellate scales.

Mello-Silva et al. 98 (holotype, SPF; isotypes, $\mathrm{BHCB}, \mathrm{K}, \mathrm{MBM}$, MO, NY, RB, SP, U).

3.Duguetia dicholepidota Martius in Martius, Fl. bras. 13(1): 22. 1841.

Bahia (Gentio do Ouro). At 500-700 m. Caatinga.
Shrub, 2-3 m tall; leaves elliptic-ovate to narrowly ovate, $7-10$ x 3-5 cm, rather densely covered with stellate scales on the lower side, primary vein impressed on the upper side; flowers yellowish green; fruit ca. $30 \mathrm{~mm}$ in diam., carpels ca. 80.

Very close to $D$. furfuracea, and possibly conspecific; the leaf indument of the lower side (stellate scales) is less dense, though.

Blanchet 2828 (lectotype, G; isolectotypes, B, BM, F, G, K, NY, OXF, P).

4. Duguetia flagellaris Huber, Bol. Mus. Paraense Hist. Nat. 5: 355. 1909.

Espírito Santo (Linhares). At sea level. Forest.

Flagelliflorous shrub, ca. $0.5 \mathrm{~m}$ tall; leaves narrowly elliptic, 13-20 x 4-5 cm, sparsely covered with stellate scales on the lower side, primary vein impressed on the upper side; flowers red; fruit brownish pink, ca. $15 \mathrm{~mm}$ in diam., carpels ca. 10.

This flagelliflorous species has up to now only been collected in N and NW South America. Its first collection from Espírito Santo forms a remarkable extension of the distribution range of this species. This description is based on the specimen collected in Espírito Santo; in this shrub the flagella did not exceed $25 \mathrm{~cm}$, whereas in Amazonian material they can grow out up to $4 \mathrm{~m}$ long!

Maas et al. 8823 (CVRD, U).

5. Duguetia furfuracea (A.F.C.P. de Saint-Hilaire) Bentham \& Hooker filius, Gen. pl. 1: 24. 1862.

Bahia (Barreiras, Caetité, Correntina, Jacobina, Lençois, Morro do Chapéu, Mucujê, Palmeiras, Piatã, Rio de Contas, São Desiderio, Vitória da Conquista), Distrito Federal (Brasília), Goiás (Água Fria, Corumbaíba, Cristalina, Divinópolis de Goiás, Mineiros, Niquelândia, Piranhas, Posse, Rio Verde, Santa Cruz de Goiás), Minas Gerais (Belo Horizonte, Botumirim, Brumadinho, Buenópolis, Carbonita, Conceição do Mato Dentro, Corinto, Diamantina, Francisco Sá, Grão-Mogol, 
Itacambira, Itamarandiba, Januária, Joaquim Felício, Lavras, Nova Ponte, Oliveira, Paracutu, Patrocínio, Perdizes, Rio Pardo de Minas, Rio Vermelho, Santana do Riacho, São Roque de Minas, Tiradentes, Uberlândia), Rio de Janeiro (Rio de Janeiro), São Paulo (Agudos, Angatuba, Araraquara, Assis, Avanhandava, Botucatu, Cabreúva, Cajuru, Campinas, Casa Branca, Cássia dos Coquieros, Emas, Iaras, Itararé, Itirapina, Itú, Jundiaí, Luiz Antônio, Moji-Guaçu, Moji-Mirim, Piraçununga, Santa Fé do Sul, Santa Rita do Passa Quatro, São Carlos, São Manuel, São Pedro, Sorocaba, Suzanópolis, Votuporanga). At 0-1400 m. Cerrado, very common.

Shrub, 0.5-2 m tall; leaves narrowly elliptic to narrowly obovate, 9-14 x 3-5 cm, densely covered with stellate hairs and scales on the upper side, totally covered with stellate scales on the lower side, primary vein impressed on the upper side; flowers red; fruit $30-50 \mathrm{~mm}$ in diam., carpels 70-140.

Harley et al. 16717 (CEPEC, IPA, K, MO, NY, P, U, US).

6 Duguetia lanceolata A.F.C.P. de Saint-Hilaire, Fl. Bras. merid. 1: 35.t. 7. 1825.

Goiás (Caldas Novas, Ipameri), Minas Gerais (Araguari, Lagoa Santa, Perdizes, Uberlândia), Rio de Janeiro (Itaipava, Petrópolis, Rio de Janeiro), São Paulo (Anhembi, Botucatu, Campinas, Helvétia, Ipeúna, Jaboticabal, Jundiaí, Moji-Guaçu, Queluz, Pindorama, Piracicaba, São José dos Campos, São Paulo, Tapiratiba). At 0-900 m. Forest or cerrado.

Tree or shrub, 8-20 m tall; leaves shiny, narrowly elliptic to elliptic, $6-10 \times 2.5-4 \mathrm{~cm}$, sparsely to rather densely covered with stellate scales on the lower side, primary vein impressed on the upper side; flowers red; fruit red, 40-60 $\mathrm{mm}$ in diam., carpels 30-80.

This species is closely related to $D$. glabriuscula, with which it shares red petals and an upper bract which is placed just under the sepals.

Maas et al. 8043 (LPZ, U, UEC, ULM, WU).
7. Duguetia magnolioidea Maas, Bot. Jahrb. Syst. 118: 198. f. 5. 1996.

Bahia (Ilhéus, Una), at sea level. Restinga.

Tree, 3-8 m tall; leaves narrowly elliptic to narrowly ovate, $18-25 \times 5-8 \mathrm{~cm}$, densely covered with long, erect stellate hairs on the lower side, primary vein impressed on the upper side; flowers yellow; fruit 40-50 x 30-35 $\mathrm{mm}$, carpels 150-200.

This species is typical by its very large, magnolia-like flowers.

Jardim et al. 1073 (CEPEC, NY).

8. Duguetia marcgraviana Martius in Martius, Fl. bras. 13(1): 25. 1841.

Goiás (Campinaçu, Colinas do Sul, Minaçu, Niquelândia, Serranópolis), Tocantins (Formoso do Araguaia, Tocantinópolis). At 0-900 m. Forest or cerrado.

Tree, 3-25 m tall; leaves narrowly ovate to narrowly elliptic, $10-23$ x 3-6.5 cm, densely covered with stellate scales on the lower side, primary vein impressed on the upper side; flowers cream; fruit red, 40-50 $\mathrm{mm}$ in diam., carpels 200-350.

Prance \& Silva 59551 (F, GH, K, NY, $\mathrm{S}, \mathrm{U}, \mathrm{US})$.

9. Duguetia microphylla (R.E. Fries) R.E. Fries, Acta Horti Berg. 6(6): 16. 1919.

Rio de Janeiro (Nova Friburgo, Petrópolis). At 700-1100 m. Forest.

Tree, 2.5-22 m tall; leaves narrowly ovate, 6-12 x 1.5-2 cm, rather densely to sparsely covered with stellate scales on the lower side, primary vein impressed on the upper side; flowers cream; fruit $40-50 \mathrm{~mm}$ in diam., carpels ca. 40.

This species is typical by very narrow leaves and very flat, hardly protruding fruiting carpels.

Amorim et al. 261 (RB, U).

10. Duguetia moricandiana Martius in Martius, Fl. bras. 13(1): 22. 1841.

Bahia (Salvador). At sea level. Restinga, dunes on white sand. 
Tree or shrub, 1.5-5 m tall; leaves elliptic, $5-10 \times 2.5-6 \mathrm{~cm}$, densely to sparsely covered with stellate scales on the lower side, primary vein impressed on the upper side; flowers yellow; fruit 35-40 mm in diam., carpels ca. 60.

Mori et al. 14078 (CEPEC, K, NY).

11. Duguetia pohliana Martius in Martius, Fl. bras. 13(1): 24. 1841.

Rio de Janeiro (Paracambi, Rio de Janeiro). Elevation unknown. Forest.

Tree, 10-15 $\mathrm{m}$ tall; leaves narrowly elliptic, slightly falcate, $12-23$ x 3-5 cm, densely covered with long, erect stellate hairs on the lower side, primary vein impressed on the upper side; flowers red; fruit $3-4.5 \mathrm{~cm}$ in diam., carpels ca. 75 .

Carauta 6363 (GUA).

12. Duguetia restingae Maas, Bot. Jahrb. Syst. 118: 210. f. 10. 1996.

Bahia (between Ubaitaba and Maraú). At sea level. Restinga.

Tree, $10 \mathrm{~m}$ tall; leaves narrowly elliptic, $37-45 \times 13-16 \mathrm{~cm}$, densely covered with long, erect stellate to simple hairs on the lower side, primary vein impressed on the upper side; flowers unknown; fruit 70 x $50 \mathrm{~mm}$, carpels ca. 150.

Only once collected.

Carvalho et al. 169 (holotype, CEPEC).

13. Duguetia reticulata Maas, Bot. Jahrb. Syst. 118: 212. f. 11. 1996.

Bahia (Mucuri). At sea level. Forest.

Tree, 8-10 m tall; leaves elliptic to narrowly elliptic, $15-19 \times 5-8 \mathrm{~cm}$, sparsely covered with stellate scales on the lower side, primary vein impressed on the upper side; flowers pinkish; fruit $35-50 \mathrm{~mm}$ in diam., carpels ca. 200.

Mori et al. 10553 (holotype, CEPEC; isotypes, $\mathrm{K}, \mathrm{NY}, \mathrm{U}$ ).

14. Duguetia riedeliana R.E. Fries, Bull. Herb. Boissier, sér. 2. 7: 1002. 1907.

Rio de Janeiro (Armação dos Búzios,
Cabo Frio, Rio de Janeiro). From sea level to $120 \mathrm{~m}$. Semideciduous low restinga forest on colluvial-alluvial soil.

Tree or shrub, 4-6 m tall; leaves narrowly elliptic to narrowly ovate, $5-14 \times 2-5 \mathrm{~cm}$, sparsely covered with stellate scales on the lower side, primary vein impressed on the upper side; flowers cream; fruit yellowish brown, inner side orange, fleshy and edible, to $7.5 \mathrm{~cm}$ in diam., carpels ca. 150 .

Maas et al. 8819 (RB, SPF, U).

15. Duguetia rotundifolia R.E. Fries, Bull. Herb. Boissier, sér. 2. 7: 1003. 1907.

Goiás (Mission of Duro, nowadays Mun. Dianópolis). Cerrado.

Tree or shrub, ca. $1 \mathrm{~m}$ tall; leaves elliptic to orbicular, $3-5 \times 2.5-3.5 \mathrm{~cm}$, sparsely covered with stellate scales on the lower side, primary vein slightly raised on the upper side; flower colour unknown; fruit unknown, flowering carpels ca. 60.

This species is very typical by orbicular and emarginate leaves! It has been only once collected.

Gardner 2998 (holotype, K).

16. Duguetia salicifolia R.E. Fries, Acta Horti Berg. 12(1): 48.1934.

São Paulo (Santo André). At 800-1100 m. Forest.

Tree, $2.5-15 \mathrm{~m}$ tall; leaves narrowly elliptic, 7-12 x 2-3.5 cm, rather densely to densely covered with stellate scales on the lower side, primary vein impressed on the upper side; flowers greenish yellow; fruit 55-80 mm in diam., carpels 60-100.

Cordeiro et al. 914 (SP, U).

17. Duguetia scottmorii Maas, Bot. Jahrb. Syst. 118: 221. f. 14. 1996.

Bahia (Uruçuca). At sea level. Forest.

Tree, $25 \mathrm{~m}$ tall; leaves narrowly elliptic, $5-8 \times 1.5-2.5 \mathrm{~cm}$, sparsely to rather densely covered with stellate scales on the lower side, primary vein impressed on the upper side; flowers unknown; fruit 70-110 x 50-80 mm, carpels ca. 150. 
Only once collected.

Mori \& Kallunki 9920 (holotype, CEPEC; isotypes, $\mathrm{K}, \mathrm{MO}$, TEX, $\mathrm{U}$ ).

18. Duguetia sessilis (Velloso) Maas, Candollea 49: 424. 1994. Rio de Janeiro (Rio de Janeiro, Saquarema). At sea level. Restinga forest, very common.

Flagelliflorous tree or shrub, to $8 \mathrm{~m}$ tall; leaves elliptic toovate, $3.5-15 \times 1.5-4.5 \mathrm{~cm}$, sparsely covered with entire to stellate scales on the lower side, primary vein flat on the upper side; flowers red to pink with a scent of apples; fruit pinkish-white, 25-30 x 30-45 mm, carpels 10-20.

This species is typical by its flagelliform inflorescence, and a primary vein of the lamina which is flat (!) on the upper side.

Maas et al. 8838 (RB, SPF, U).

19. Duguetia sooretamae Maas, Bot. Jahrb. Syst. 121: 486. f. 18-21. 1999.

Espírito Santo (Conceição da Barra, Linhares). At sea level. Restinga or Muçununga forest on coarse white sand, very common.

Tree or shrub, 1.5-5 $\mathrm{m}$ tall; leaves narrowly ovate, $7-12$ x $1.5-4 \mathrm{~cm}$, totally covered with stellate scales on the lower side, primary vein impressed on the upper side; flowers green to white; fruit greyish, $40 \mathrm{~mm}$ in diam., basal part of carpels orange, carpels $>200$.

Local name: Pindaíba-coroa.

Maas et al. 8827 (CVRD, U).

\section{Duguetia sp. nov.}

Bahia (Una). At low elevation. Forest.

Shrub, $5 \mathrm{~m}$ tall; leaves narrowly elliptic, $22-28 \times 5-7 \mathrm{~cm}$, rather densely covered with erect stellate hairs on the lower side, primary vein impressed on the upper side; flower colour unknown; fruit unknown, flowering carpels ca. 30.

Santos \& Alves 209 (CEPEC, U).

\section{Ephedranthus S. Moore}

Leaves with primary vein impressed on the upper side; indument of simple hairs; bracts several per flower; flowers solitary, axillary, uni- or bisexual, sepals free, petals free, green to cream; fruit apocarpous, monocarps 8-12, indehiscent, free, 1-seeded.

Fries, R.E. 1931. Revision der Arten einiger Anonaceen-Gattungen II. Acta Horti Berg. 10(2): 175-178.

\section{Ephedranthus sp. 1}

Bahia (Prado), Espírito Santo (Linhares). At sea level. Forest.

Tree, $15-30 \mathrm{~m}$ tall; leaves narrowly elliptic to narrowly obovate, $6-12 \times 3.5-5.5 \mathrm{~cm}$, rather densely to sparsely hairy on the lower side, secondary veins strongly impressed on the upper side, tertiary veins slightly reticulate on the upper side; flowers pale cream; monocarps $8-12,20-25$ x 12-13 mm.

Local name: Pindaíba-preta.

Maas et al. 8826 (CVRD, U).

\section{Ephedranthus sp. 2}

Bahia (Santa Cruz Cabrália), Espírito Santo (Linhares), Minas Gerais (Caratinga). At 0-600 m. Forest.

Tree, 20-31 m tall; leaves elliptic to narrowly elliptic, subglabrous on the lower side, 8-12 x 3-4 cm, secondary veins strongly impressed on the upper side, tertiary veins strongly reticulate on the upper side, subglabrous on the lower side; flowers green; fruit not seen.

This species may be the same as Ephedranthus spec. 1.

Local name: Pindaíba-preta.

Folli 465 (CVRD, SPF, U).

\section{Ephedranthus sp. 3}

Espírito Santo (Linhares). At sea level. Forest.

Tree, $30 \mathrm{~m}$ tall; young twigs densely hairy; young leaves elliptic, 5-6 x 2-3 cm, rather densely hairy on the upper side, very densely hairy on the lower side; flowers green; fruit not seen.

Folli 414 (CVRD, SPF, U). 


\section{Ephedranthus sp. 4}

Goiás (Cavalcante, Colinas do Sul, Minaçu, Niquelândia). Galery forest.

Tree, of unknown height; young twigs and pedicels densely hairy; leaves elliptic, 6-12 $\mathrm{x}$ 4-6 cm, glabrous except for the hairy primary vein on the upper side, primary and secondary veins strongly impressed on the upper side; flowers not seen; monocarps ellipsoid, 15-20 x 7-10 mm, yellowish-cream to red when immature, maturing wine red; stipes 3-5 mm long.

Santos et al. 58 (CEN, SPF).

\section{Guatteria Ruiz \& Pavón}

Leaves with impressed primary vein on the upper side; pedicels with suprabasal articulation; indument of simple hairs; bracts 2 per flower; flowers mostly solitary, axillary, sepals free, petals free, green, cream to yellow, inner ones imbricate; fruit apocarpous, monocarps many, indehiscent, 1 -seeded.

Fries, R.E. 1939. Revision der Arten einiger Anonaceen-Gattungen II. Acta Horti Berg. 12(3): 289-577.

1. Guatteria acutiflora Martius in Martius, Fl. bras. 13(1): 29. 1841, non Wallich

Espírito Santo (Serra). Forest.

Tree, 3-5 m tall; leaves chartaceous, black when dry, narrowly elliptic, 9-14 x 3-4.5 cm, sparsely hairy on the lower side; pedicels 10 mm long; monocarps not seen.

Wied und Neuwied s.n. (holotype, BR).

2. Guatteria acutipetala R.E. Fries, Acta Horti Berg. 12(3): 324. t. 13. 1939.

Minas Gerais (Ouro Preto), Rio de Janeiro (Petrópolis, Rio de Janeiro, Teresópolis). Forest.

Shrub of unknown height; leaves chartaceous, narrowly elliptic, 9-14 x $2.5-5 \mathrm{~cm}$, sparsely covered with appressed hairs on the lower side; pedicels 30-55 mm long; monocarps 10-11 x 4-5 mm, stipes $15 \mathrm{~mm}$ long.

Macedo 3031 (SPF).
3 Guatteria australis A.F.C.P. de Saint-Hilaire, Fl. Bras. merid. 1: 37. 1825.

Guatteria asterantha R.E. Fries

Guatteria hilariana Schlechtendal

Guatteria neglecta R.E. Fries

Guatteria nigrescens Martius

Guatteria parvifolia R.E. Fries

Guatteria polycarpa R.E. Fries subsp. polycarpa

Guatteria salicifolia R.E. Fries subsp. drupacea R.E. Fries

Guatteria sordida R.E. Fries

Guatteria tenuis R.E. Fries

Bahia (Maraú, Uruçuca), Espírito Santo (Santa Teresa), Minas Gerais (Carangola, Divino, Lima Duarte, Viçosa), Rio de Janeiro (Rio de Janeiro), São Paulo (Arandu, Atibaia, Bananal, Cananéia, Caraguatatuba, Cubatão, Cunha, Iaras, Iguape, Itaberá, Itararé, Jundiaí, Juquitiba, Itararé, Salesópolis, Santo André, Santos, São Luiz do Paraitinga, São Paulo, Serra Negra, Tapiraí). Forest.

Tree or shrub, 4-15 m tall; leaves chartaceous, narrowly elliptic, $5-11 \times 2-5 \mathrm{~cm}$, sparsely covered with appressed hairs on the lower side; pedicels 15-25 mm long; monocarps 7-9 x 5-6 mm, stipes 3-20 mm long.

Extremely variable species!! Probably more taxa are involved.

A.F.C.P. de Saint-Hilaire s.n. (holotype, P).

4. Guatteria blanchetiana R.E. Fries, Acta Horti Berg. 12(3): 331. t. 14. 1939.

Bahia (Ilhéus). At sea level. Forest.

Tree or shrub, $6 \mathrm{~m}$ tall; leaves chartaceous, narrowly elliptic, 12-20 x 4-5.5 $\mathrm{cm}$, sparsely covered with erect hairs on the lower side; pedicels 30-40 mm long; monocarps not seen.

$\mathrm{BM}, \mathrm{P})$.

Blanchet 2114 (holotype, G; isotypes,

5. Guatteria burchellii R.E. Fries, Acta Horti Berg. 12(3): 398. 1939.

Rio de Janeiro (Frechal to Magé). Forest.

Cauliflorous tree, of unknown height; leaves chartaceous, narrowly elliptic, 18-24 x 
6-7.5 cm, sparsely covered with erect hairs on the lower side; pedicels 35-40 mm long; monocarps not seen.

This species is typical in being cauliflorous (producing flowers at the main trunk) and in having large leaves covered with erect hairs on the lower side. Probably the same as $G$. ferruginea, which is the oldest name!

Amorim et al. 818 (CEPEC, U).

6. Guatteria campestris R.E. Fries, Acta Horti Berg. 12(3): 402. 1939.

Minas Gerais (Araçuaí). Campo.

Tree or shrub, of unknown height; leaves coriaceous, narrowly elliptic, $10-17$ x 4-5 cm, densely covered with erect hairs on the lower side; pedicels to $12 \mathrm{~mm}$ long; monocarps not seen.

Probably a synonym of $G$. odontopetala. Glaziou 14466 (holotype, B; isotypes, K, P).

7. Guatteria candolleana Schlechtendal, Linnaea 9: 325. 1835.

Bahia (Itapebi, Porto Seguro, Prado, Santa Cruz Cabrália), Espírito Santo (Aracruz, Linhares, São Mateus, Sumidouro), Rio de Janeiro (Magé, Petrópolis, Resende). At 0-50 $\mathrm{m}$. Forest or restinga, sandy soil.

Shrub or tree, 5-20 m tall; leaves chartaceous to coriaceous, narrowly elliptic, 6-15 x 2.5-4.5 cm, sparsely covered with erect brown hairs on the lower side especially on the midrib; bracts to $16 \mathrm{~mm}$ long; pedicels $20-40$ mm long; monocarps $6 \times 3 \mathrm{~mm}$, stipes $5 \mathrm{~mm}$ long.

This species is typical in having long, patent ferruginous hairs on the young twigs, pedicels, sepals, and petals. The leaf base is rounded or cordate.

Mori 10901 (NY, U).

8. Guatteria clavigera R.E. Fries, Acta Horti Berg. 12(3): 334. f. 5 g \& h. 1939.

São Paulo (São Paulo). Forest.

Tree or shrub, of unknown height; leaves chartaceous, narrowly obovate, 10-18 x 3-4.5 $\mathrm{cm}$, sparsely covered with appressed hairs on the lower side; pedicels 30-45 mm long; monocarps $15-17$ x 6-7 mm, stipes 30-40 mm long.

Koscinsky 214 (holotype, S).

9. Guatteria curvinervia R.E. Fries, Acta Horti Berg. 12(3): 317. t. 11. 1939.

Rio de Janeiro (Nova Friburgo), São Paulo (Barretos, Jundiaí). Forest.

Tree or shrub, to $5 \mathrm{~m}$ tall; leaves chartaceous, narrowly elliptic, 10-15 x 2.5-3.5 $\mathrm{cm}$, sparsely covered with appressed hairs on the lower side; pedicels 20-35 mm long; monocarps 8-9 $\mathrm{x} 4 \mathrm{~mm}$, stipes $12-18 \mathrm{~mm}$ long.

Brade 7238 (B).

10. Guatteria densicoma Martius in Martius, Fl. bras. 13(1): 32. 1841.

Bahia (Ilhéus). Forest.

Tree, $12 \mathrm{~m}$ tall; leaves chartaceous, narrowly ovate, $8-14$ x 3-4.5 cm, sparsely covered with appressed hairs on the lower side; pedicels 25-30 mm long; monocarps 10-11 x $4.5 \mathrm{~mm}$, stipes $15-20 \mathrm{~mm}$ long.

Martius 711 (holotype, M; isotypes, HAL, P).

11. Guatteria dimorphopetala R.E. Fries, Acta Horti Berg. 12(3): 333. f. 5c. 1939.

Bahia (between Vitória and Bahia). Forest.

Tree or shrub, of unknown height; leaves chartaceous, densely verrucose, narrowly elliptic-obovate, $10-15$ x 2.5-4.5 cm, sparsely covered with appressed hairs on the lower side; pedicels $35-50 \mathrm{~mm}$ long, inner petals twice as large as the outer ones; monocarps not seen.

Sellow 175 (holotype, B).

12. Guatteria elliptica R.E. Fries, Acta Horti Berg. 12(3): 445. f. 19c \& d. 1939.

Rio de Janeiro (São Fidelis). Forest.

Tree or shrub, of unknown height; leaves chartaceous, elliptic, 10-15 x 5-6 cm, rather densely covered with golden appressed hairs on the lower side; pedicels $10-15 \mathrm{~mm}$ long; monocarps not seen.

Glaziou 9605 (holotype, C; isotypes, K, P). 
13. Guatteria ferruginea A.F.C.P. de Saint-Hilaire, Fl. Bras. merid. 1: 38. 1825.

Bahia (Ilhéus, Uruçuca, Una), Espírito Santo (Santa Bárbara do Caparaó), Minas Gerais (Leopoldina), Rio de Janeiro (Cachoeiras de Macacu, Nova Friburgo, Nova Iguaçu, Piraí). Forest.

Cauliflorous tree, 4-12 m tall; leaves chartaceous, elliptic to narrowly ovate, $15-45$ $x$ 7-15 cm, densely covered with erect ferruginous hairs on the lower side (as are the young twigs, sepals, and petals); pedicels 5-15 mm long; monocarps 9-10 x 5-6 mm, stipes 11-13 mm long.

This is probably conspecific with $G$. burchellii (in Utrecht found under that species!). The material in CEPEC is also identified as G. ferruginea.

Braga et al. 1697 (U).

14. Guatteria fruticosa R.E. Fries, Acta Horti Berg. 12(3): 312.t. 6. 1939.

São Paulo (São José dos Campos, São Paulo). Campos.

Shrub, $3 \mathrm{~m}$ tall; leaves chartaceous, narrowly elliptic, $8-15 \times 2.5-3.5 \mathrm{~cm}$, densely covered with erect or appressed hairs on the lower side; pedicels 15-25 mm long; monocarps not seen.

Löfgren 531 (holotype, S).

15. Guatteria glabrescens R.E. Fries, Acta Horti Berg. 12(3): 311. t. 5. 1939.

Rio de Janeiro (Rio de Janeiro). Forest.

Tree, of unknown height; leaves chartaceous, narrowly obovate, 10-18 x 2-3 $\mathrm{cm}$, sparsely covered with appressed hairs on the lower side; pedicels $15-25 \mathrm{~mm}$ long; monocarps 10-12 x 5-6 mm, stipes 7-10 mm long.

Kuhlmann RB4483 (holotype, S; isotype, $\mathrm{RB}$ ).

16. Guatteria gomeziana A.F.C.P. de Saint-Hilaire, Fl. Bras. merid. 1: 36. 1825.

Minas Gerais (Aroeirão, Campos, Itajuru, Rio Piracicaba, Santa Bárbara). Forest.
Tree, to $10 \mathrm{~m}$ tall; leaves chartaceous, narrowly rhombic-elliptic, $8-15 \times 2.5-4.5 \mathrm{~cm}$, sparsely to rather densely covered with appressed hairs on the lower side; pedicels $40-50 \mathrm{~mm}$ long, apically thickened to $3 \mathrm{~mm}$ in diam.; monocarps not seen.

Hoehne SP5066 (SP).

17. Guatteria hookeri A.F.C.P. de Saint-Hilaire \& Tulasne, Ann. Sci. Nat., Bot. sér. 2. 17: 132. 1842.

Rio de Janeiro (Rio de Janeiro, Teresópolis). Forest.

Shrub, 3-4 m tall; leaves chartaceous, narrowly elliptic, 6-12 x 1.5-4 cm, sparsely covered with erect hairs on the lower side; pedicels 25-45 mm long; monocarps 10-11 x 4.5-5 mm, stipes 5-8 mm long.

Miers 4018 (K).

18. Guatteria klotzschiana Martius in Martius, Fl. bras. 13(1): 32. 1841.

Rio de Janeiro ("Tocaja”), São Paulo (Ubatuba). Forest.

Tree or shrub, of unknown height; leaves chartaceous, narrowly elliptic, $6-12 \times 2.5-4 \mathrm{~cm}$, sparsely covered with appressed hairs on the lower side; pedicels 25-30 mm long; monocarps 8 x $5 \mathrm{~mm}$, stipes $15-22 \mathrm{~mm}$ long.

Glaziou 7506 (B, C, P).

19. Guatteria latifolia (Martius) R.E. Fries, Acta Horti Berg. 12(3): 326. f. 4a. 1939.

Rio de Janeiro (Itatiaia, Magé, Nova Iguaçu). At $1000 \mathrm{~m}$. Forest.

Tree, of unknown height; leaves chartaceous, elliptic to narrowly elliptic, 10-19 x 5-7 cm, sparsely covered with appressed hairs on the lower side; pedicels $25 \mathrm{~mm}$ long; monocarps $10-11$ x $5 \mathrm{~mm}$, stipes $20-30 \mathrm{~mm}$ long.

Rodrigues \& Daly 1252 (U).

20. Guatteria lutea A.F.C.P. de Saint-Hilaire, Fl. Bras. merid. 1: 37. 1825.

Guatteria reticulata R.E. Fries

Minas Gerais (Ouro Preto), Rio de Janeiro 
(Teresópolis), São Paulo (Serra da Bocaina). Forest.

Tree to shrub, 3.5-4.5 m tall; leaves chartaceous, narrowly elliptic, 10-16 x 3-4.5 $\mathrm{cm}$, sparsely covered with appressed hairs on the lower side; bracts to $30 \mathrm{~mm}$ long; pedicels 30-60 mm long; flowers yellow; monocarps 10 x $6 \mathrm{~mm}$, stipes $11-13 \mathrm{~mm}$ long.

Lutz 733 (S).

21. Guatteria macropus Martius in Martius, Fl. bras. 13(1): 28. t. 8. 1841.

Bahia (Ilhéus, Itacaré, Santo Antônio de Jesus), Espírito Santo (Linhares). Forest.

Shrub or tree, 2.5-9 m tall; leaves chartaceous, narrowly elliptic, 12-16 x 2.5-3.5 $\mathrm{cm}$, long-acuminate to long-acute, rather densely covered with erect hairs on the lower side; pedicels 80-120 mm long; monocarps not seen.

This species is characterized by young twigs which are densely covered with erect, ferruginous hairs, very long pedicels, and reflexed sepals.

Pirani \& Kallunki 2725 (HUEFS, MBM, NY, RB, SPF, UB).

22. Guatteria mexiae R.E. Fries, Acta Horti Berg. 12(3): 344. 1939.

Minas Gerais (Carangola, Serro), São Paulo (between Rio Pirituba and Sorocaba, São José dos Campos). To 900 m. Forest.

Shrub, 3-4 m tall; leaves chartaceous, narrowly elliptic-ovate, $8-13 \times 2-3.5 \mathrm{~cm}$, densely but later sparsely covered with erect hairs on the lower side; pedicels 20-60 mm long; monocarps $9-11 \times 5-5.5 \mathrm{~mm}$, stipes $4-6 \mathrm{~mm}$ long.

Mexia 4249 (holotype, S; isotypes, BM, $\mathrm{K}, \mathrm{U})$.

23. Guatteria minarum R.E. Fries, Acta Horti Berg. 12(3): 346. t. 16. 1939.

Minas Gerais (Viçosa). At $700 \mathrm{~m}$. Secondary forest.

Tree, $6 \mathrm{~m}$ tall; leaves chartaceous, narrowly elliptic, $10-17$ x 2-3 cm, densely but later sparsely covered with appressed hairs on the lower side; pedicels $20-45 \mathrm{~mm}$ long; monocarps 9 x 5-6 mm, stipes 8-13 mm long. Mexia 5130 (holotype, S; isotypes, BM, F, K, U).

24. Guatteria mosenii R.E. Fries, Acta Horti Berg. 12(3): 321. 1939.

São Paulo (Santo Antônio de Jardim, São Simão). Forest.

Shrub, of unknown height; leaves chartaceous, linear, $12-18 \times 2-2.5 \mathrm{~cm}$, sparsely covered with appressed hairs on the lower side; pedicels 18-28 mm long; monocarps 11-12 x $5.5 \mathrm{~mm}$, stipes $10-13 \mathrm{~mm}$ long.

This species is very typical by its linear leaves. Only twice collected.

Mosén 4002 (holotype, S).

25. Guatteria notabilis Mello-Silva \& Pirani, Bol. Bot. Univ. São Paulo 10: 44. f. 1-23. 1988.

Bahia (Morro do Chapéu), Minas Gerais (Botumirim, Couto de Magalhães de Minas, Datas, Diamantina, Grão-Mogol, Joaquim Felício, Serro). At 1000-1300 m. Forests or campo rupestre on rocky slopes.

Tree, 2-9 m tall; leaves coriaceous, verrucose, narrowly elliptic, $13-20$ x 3.5-6 cm, densely covered with erect, ferruginous hairs on the lower side (velutinous); pedicels 9-17 mm long; monocarps 15 x 8 mm, stipes absent.

Very typical by its young twigs, leaves, and flowers which are covered with a velutinous, brown indument, by its terminal flowers, and sessile monocarps.

Mello-Silva et al. CFCR8062 (holotype SPF; isotypes, F, K, MO, NY, RB, SP, U).

26. Guatteria odontopetala Martius in Martius, Fl. bras. 13(1): 33. t. 11. 1841.

Minas Gerais (Campo Alegre to Virgem da Lapa, Grão-Mogol, Manoel Pereira, Marliéria, Minas Novas, Santa Bárbara, Serro, Uruana de Minas). Forest.

Tree, of unknown height; leaves chartaceous, narrowly elliptic, 12-18 x 4-5.5 $\mathrm{cm}$, sparsely covered with erect hairs on the 
lower side; pedicels 20-40 mm long; monocarps $14 \times 7 \mathrm{~mm}$, stipes $10-18 \mathrm{~mm}$ long.

Duarte 10529 (BR, G, L, LE, M, MO, NY, R, RB, U, US, W, Z).

27. Guatteria oligocarpa Martius in Martius, Fl. bras. 13(1): 33. 1841.

Guatteria bahiensis R.E. Fries

Guatteria cauliflora Martius

Guatteria schlechtendaliana Martius

Bahia (Ilhéus, Maraú, Porto Seguro, Santa Cruz Cabrália, Una, Uruçuca), Espírito Santo (Linhares). At sea level. Forest.

Tree, 4-15 m tall; leaves mostly coriaceous, narrowly elliptic to elliptic, 10-30 x $3.5-12 \mathrm{~cm}$, sparsely covered with appressed hairs on the lower side; pedicels $15-20 \mathrm{~mm}$ long; monocarps, 9-13 x 6-10 mm, stipes 3-12 mm long.

Characterized by large, almost globose monocarps (resembling those of Pseudoxandra) and large, often obtuse-based leaves.

$$
\text { Callejas } 1714 \text { (CEPEC, NY, RB, U). }
$$

28. Guatteria peckoltiana R.E. Fries, Acta Horti Berg. 12(3): 457. f. 21c. 1939.

Rio de Janeiro (Cantagalo). Forest.

Tree or shrub, of unknown height; leaves chartaceous, narrowly elliptic, 8-12 x 1.5-2.3 $\mathrm{cm}$, densely covered with erect hairs on the lower side; pedicels 10-15 mm long; monocarps not seen.

Probably the same as G. sellowiana?

Only once collected.

Peckolt 362 (holotype, BR).

29. Guatteria penduliflora R.E. Fries, Acta Horti Berg. 12(3): 341. t. 15. 1939.

Rio de Janeiro (without exact locality). Forest.

Tree, of unknown height; leaves chartaceous to coriaceous, narrowly elliptic to narrowly obovate, $8-12$ x 2-4.5 cm, densely but soon sparsely covered with hairs ("decumbentibus") on the lower side; pedicels 20-40 mm long; monocarps not seen.
Only once collected.

Freire Allemão s.n. (holotype, G).

30. Guatteria pogonopus Martius in Martius, Fl. bras. 13(1): 34. 1841.

Bahia (Ilhéus, Nazaré, Santo Antônio de Jesus, Valença, between Vitória and Bahia), Espírito Santo (Aracruz, Domingos Martins, Linhares, Santa Teresa, Serra do Rio), Minas Gerais (Marliéria). At 600-1000 m. Forest.

Tree, 4-10 m tall; leaves chartaceous, narrowly elliptic to elliptic, $20-35 \times 8-13 \mathrm{~cm}$, sparsely covered with appressed hairs on the lower side; pedicels 10-15 mm long; monocarps 10 x $6 \mathrm{~mm}$, stipes $12-15 \mathrm{~mm}$ long.

Typical by very large leaves often with a rounded base.

Kollmann et al. 1350 (MBML, SPF).

31. Guatteria pohliana Schlechtendal, Linnaea 9: 321. 1835.

Minas Gerais (Caparaó, Catas Altas, Diamantina, Lima Duarte, Ouro Preto, Santana do Riacho, Santo Antônio do Itambé). At 950-1350 m. Forest.

Tree, 6-13 m tall; leaves chartaceous, narrowly elliptic to narrowly ovate, 4-7 x $1.5-2.8 \mathrm{~cm}$, sparsely covered with appressed hairs on the lower side; pedicels $20 \mathrm{~mm}$ long; monocarps 8-12 x 5-7 mm, stipes 5-11 mm long.

Characterized by very small leaves.

Irwin 22483 (NY, U).

32. Guatteria psilopus Martius in Martius, $\mathrm{Fl}$. bras. 13(1): 27. t. 7, f. 1. 1841.

Rio de Janeiro (Rio de Janeiro, Teresópolis). Forest.

Tree, 6-8 m tall; leaves chartaceous, narrowly obovate, $10-15 \times 3-5 \mathrm{~cm}$, rather densely covered with appressed ("decumbentibus") hairs on the lower side; bracts to $15 \mathrm{~mm}$ long; pedicels very slender, 25-35 mm long; petals covered with yellow indument; monocarps not seen.

Riedel 1172 (B, M, S). 
33. Guatteria reflexa R.E. Fries, Acta Horti Berg. 12(3): 329. 1939. Forest?

Rio de Janeiro (Niterói, Rio de Janeiro).

Tree or shrub, of unknown height; leaves chartaceous or coriaceous, narrowly elliptic, 6-12 x 2.5-4 cm, sparsely covered with appressed hairs on the lower side; pedicels 20-30 mm long; monocarps not seen.

Glaziou 5725 (holotype, S; isotypes, B, $\mathrm{C}, \mathrm{K}, \mathrm{P}, \mathrm{RB})$.

34. Guatteria riedeliana R.E. Fries, Acta Horti Berg. 12(3): 339. f. 6a \& b. 1939.

Bahia (Ilhéus). At low elevation. Forest.

Tree or shrub, of unknown height; young twigs, young leaves, and petals densely covered with ferruginous, appressed hairs; leaves chartaceous, elliptic, 15-19 x 6-9 cm, sparsely covered with appressed ("decumbentibus") hairs on the lower side; pedicels slender, 30-40 mm long; monocarps not seen.

Only once collected

Riedel 424 (holotype, S; isotype, LE).

35. Guatteria rupestris Mello-Silva \& Pirani, Novon 4(2): 146. 1994.

Minas Gerais (Grão-Mogol, Itacambira, Joaquim Felício, Rio Vermelho, Santana do Riacho). Campo rupestre, between rocks.

Shrub or tree, 1.5-4 m tall; leaves coriaceous, narrowly obovate to elliptic, 3.5-8 $x 1.5-3 \mathrm{~cm}$, subglabrous on the lower side; pedicels $10 \mathrm{~mm}$ long; monocarps 10-17, 7-10 x 3.5-5 mm, stipes 2-7 mm long.

A very typical species by its small, coriaceous, prominently veined leaves with often rounded to slightly emarginate apex.

G. Hatschbach 41573 (U).

36. Guatteria sellowiana Schlechtendal, Linnaea 9: 323. 1835.

Guatteria pubens (Martius) R.E. Fries

Bahia (Abaíra, Barra da Estiva, Barra do Choça, Rio de Contas), Distrito Federal (Brasília), Goiás (Luziânia, Planaltina de
Goiás), Minas Gerais (Caeté, Diamantina, Ibiá, Lagoa Santa, Ouro Branco, Ouro Preto, Patrocínio, Perdizes, Rio Acima, Rio Vermelho, Santa Bárbara, Santana do Riacho, Santo Antônio do Itambé, Viçosa). At 900-1700 m. Forest (often gallery forest).

Tree or shrub, 2-12 m tall; young twigs, lower side of leaves, and monocarps densely covered with brown erect hairs; leaves coriaceous, verrucose, narrowly ovate to narrowly elliptic, 6-12 x 2-3.5 cm; pedicels 15-20 mm long; monocarps 8 x $4 \mathrm{~mm}$, stipes 10-15 mm long.

This species looks similar to $G$. schomburgkiana, but it has a much denser indument on the young twigs, and, moreover, the stipes are much longer.

Mori et al. 11304 (NY, U).

37. Guatteria silvatica R.E. Fries, Acta Horti Berg. 12(3): 330. 1939.

Rio de Janeiro (Cantagalo). Forest.

Treelet, of unknown height; leaves chartaceous, narrowly elliptic, 11-19 x 3-5 cm, densely, but soon sparsely covered with appressed ("decumbentibus") hairs on the lower side; pedicels $25 \mathrm{~mm}$ long; monocarps not seen.

Only once collected.

Peckolt 151 (holotype, BR).

38. Guatteria umbrosa R.E. Fries, Acta Horti Berg. 12(3): 455. t. 31. 1939.

Rio de Janeiro (Petrópolis). Forest.

Tree or shrub, 9-12 m tall; young leaves and lower side of leaves sparsely covered with small brown appressed hairs; leaves chartaceous, narrowly elliptic to narrowly ovate, 4-5.5 x 1-2 cm; pedicels 20-25 mm long; monocarps 7-8 x $4 \mathrm{~mm}$, stipes 7-9 mm long.

The young twigs are densely covered with brownish appressed hairs. This may well be a synonym of $G$. australis or G. sellowiana.

Only once collected.

Riedel s.n. (holotype, S; isotype, LE). 
39. Guatteria villosissima A.F.C.P. de Saint-Hilaire var. villosissima, Fl. Bras. merid. 1:38. 1825 .

Guatteria villosissima A.F.C.P. de SaintHilaire var. longepedunculata R.E. Fries

Minas Gerais (Alvorada de Minas, Belo Horizonte, Caratinga, Caeté, Catas Altas, Conceição do Mato Dentro, Congonhas do Norte, Itabirito, Juiz de Fora, Mariana, Nova Lima, Ouro Preto, Rio Piracicaba, Rio Vermelho, Santa Bárbara, Santana de Riacho, São Gonçalo do Rio Abaixo, São Sebastião de Àguas Claras, Serro, Viçosa), Rio de Janeiro (Nova Friburgo, Rio de Janeiro), São Paulo (São João do Morro Grande). At 700-1800 m. Forest, gallery forest, and cerrado.

Tree, 3-10 m tall; leaves chartaceous, verrucose on the upper side, narrowly elliptic, 5-16 x 2-4 cm, densely covered with erect hairs on both sides; pedicels 10-30 mm long; monocarps 7-8 x 4-4.5 mm, stipes 3-6 mm long.

This very common species belongs to sect. Trichoclonia, the leafy twigs and both sides of leaves are densely villose, the leaf margins are mostly distinctly reflexed.

Mexia 5277 (BM, K).

40. Guatteria xylopioides R.E. Fries, Acta Horti Berg. 12(3): 459. f. 21g. 1939.

Rio de Janeiro (Cabo Frio). At sea level. Restinga.

Tree or shrub, of unknown height; leaves coriaceous, narrowly elliptic, $10-12 \times 2-3 \mathrm{~cm}$, sparsely covered with appressed hairs on the lower side; pedicels 7-8 mm long; monocarps not seen.

Only once collected.

Glaziou 13401 (holotype, B; isotypes, K, P).

\section{Guatteria sp.}

Goiás (Caldas Novas, Ipameri). Forest.

Tree, 3-10 m tall; leaves chartaceous, oblong-elliptic to narrowly so, 10-21 x 3-7 cm, sparsely covered with appressed hairs on the lower side; pedicels $30 \mathrm{~mm}$ long; monocarps 11-12 x 6-7 mm, stipes 15-25 mm long.

This species has been tentatively identified as G. $c f$. gracilipes R.E. Fries by R. Mello-Silva. It differs, however, from this species by the shape of the leaves and their apex.

Cavalcanti 1979 (CEN, SPF).

\section{Guatteriopsis R.E. Fries}

Leaves with impressed primary vein on the upper side; pedicels with suprabasal articulation; indument of simple hairs; bracts 2 per flower; flowers mostly solitary, axillary, sepals free, petal free, cream to yellow, inner ones valvate; fruit apocarpous, monocarps many, indehiscent, 1 -seeded.

Fries, R.E. 1934. Revision der Arten einiger Anonaceen-Gattungen III. Acta Horti Berg. 12(1): 108-112.

1. Guatteriopsis blepharophylla (Martius) R.E. Fries, Acta Horti Berg. 12(1): 110. t. 6. 1934.

Minas Gerais (Rio Manso). Forest.

Tree, 5-8 $\mathrm{m}$ tall; leaves strongly verrucose, narrowly elliptic, $15-33 \times 4.5-7 \mathrm{~cm}$; pedicels 5-7 mm long; monocarps $20 \times 9 \mathrm{~mm}$.

This species is typical by its verrucose leaves with a long-acuminate apex; the inner petals are always valvate in the genus Guatteriopsis, whereas they are imbricate in Guatteria.

Glaziou 13506 (B, P).

XI. Hornschuchia Nees von Esenbeck

Leaves with impressed to raised primary vein on the upper side, sometimes with asymmetrical base; imdument of simple hairs; bracts absent (sometimes bract-like leaves present on axes of inflorescences); flowers solitary or in many-flowered inflorescences, terminal or leaf-opposed; inflorescences often flagelliform and produced from the main trunk (cauliflorous), sepals connate into a cup-shaped to saucer-shaped calyx, petals free (except in H. lianarum), whitish; fruit apocarpous, monocarps 1-3, dehiscent or not, globose to fusiform, 1-8-seeded. 
Johnson, D.M. \& Murray, N.A. 1995. Synopsis of the tribe Bocageeae (Annonaceae) with revisions of Cardiopetalum, Froesiodendron, Trigynaea, Bocagea, and Hornschuchia. Brittonia 47(3): 248-319.

1. Hornschuchia alba (A.F.C.P. de Saint-Hilaire) R.E. Fries, Acta Horti Berg. 10(2): 137.t. 2. 1931.

Rio de Janeiro (Armação dos Búzios, Cabo Frio). At sea level to $120 \mathrm{~m}$. Semideciduous low $(10 \mathrm{~m})$ restinga forest, on colluvial-alluvial soil.

Shrub, 0.5-2 m tall; leaves ovate, 5-8 x $2-3.5 \mathrm{~cm}$, primary vein flat or slightly impressed on the upper side; flowers solitary, white; monocarps 3, ca. $20 \mathrm{~mm}$ long, obovoid, verrucose, seed number unknown.

Similar to H. lianarum, but petals free. Very rare.

Maas et al. 8818 (RB, SPF, U).

2. Hornschuchia bryotrophe Nees von Esenbeck, Flora 4: 302. 1821.

Bahia (Gandu, Ibacaraí, Ilhéus, Una), Espírito Santo (Aracruz, Guarapari, Linhares, Rio Bananal), Rio de Janeiro (Rio Bonito). At sea level. Wet forest on (pale) brown sand.

Cauliflorous treelet or shrub, 0.5-4 m tall; leaves narrowly elliptic to narrowly obovate, $14-34 \times 4-11 \mathrm{~cm}$, primary vein raised to flat on the upper side, base asymmetrical; flowers in flagelliform inflorescences, white, with sweet scent; monocarps 1-3, 30-52 x 4-9 mm, seeds $2-6$.

Typical by leaves with asymmetrical base and marginal vein far from the margin, and flagelliform inflorescence.

Maas et al. 8829 (H, MBML, RB, U).

3. Hornschuchia cauliflora Maas \& van Setten, Proc. Kon. Nederl. Akad. Wetensch. C 91: f. 16 \& 17. 259. 1988.

Bahia (Itacaré, Ubaitaba). At sea level. Lowland rain forest.

Cauli- or ramiflorous treelet or shrub, 3-4 $\mathrm{m}$ tall; leaves elliptic to obovate-elliptic, 28-32 $x 10-15 \mathrm{~cm}$, primary vein impressed on the upper side; flowers in contracted woody inflorescences, white; monocarps 1-3, 45-70 x 6-7 mm, seeds 4-6.

Typical by very large, subcoriaceous leaves.

Sobral et al. 5749 (CEPEC, ICN, NY, OWU, SPF).

4. Hornschuchia citriodora D.M. Johnson, Contr. Univ. Michigan Herb. 19: 259. f. 1. 1993.

Bahia (Alcobaça), Espírito Santo (Guarapari, Linhares). At sea level. Forest on pale brown sand.

Tree, 3-5 $\mathrm{m}$ tall; leaves thick and shiny, narrowly elliptic, $13-21 \times 4-8 \mathrm{~cm}$, primary vein flat or slightly impressed on the upper side; flowers solitary, white; monocarps 1-3, 30-45 x 15-28 mm, shiny, seeds 6-8.

Typical by large leaves and single flowers. Maas et al. 8828 (H, MBML, RB, U).

5. Hornschuchia leptandra D.M. Johnson, Brittonia 47: 310. f. 25 C \& D, 27A-E. 1995.

Bahia (Ilhéus, Itabuna, Santo Antônio de Jesus, Una). At sea level. Lowland forest.

Cauliflorous tree, 3-4 m tall; leaves narrowly elliptic to narrowly obovate, $26-42 \mathrm{x}$ $8-12 \mathrm{~cm}$, primary vein raised to slightly impressed on the upper side; flowers in flagelliform inflorescences with short woody axes, white; monocarps 1-2, 53-57 x 12-17 mm, seeds ca. 4.

This species is typical by a flagelliform inflorescence, but lacking the asymmetrical leaf base and typical marginal vein of $H$. bryotrophe.

Amorim et al. 858 (NY, U).

6. Hornschuchia lianarum D.M. Johnson, Brittonia 47: 300. f. 4E, 21C, 22A-G. 1995.

Bahia (Barra do Choça, Cachoeira, Feira de Santana, Vitória da Conquista). At 200-900 m. Semideciduous forest ("mata de cipó").

Shrub or treelet, 1.5-7 m tall; leaves narrowly ovate, $6-11 \times 3-5 \mathrm{~cm}$, primary vein 
impressed on the upper side; flowers solitary, white; monocarps 1,10 x $10 \mathrm{~mm}$, rugose, seeds 2 .

Related to $H$. alba by having relatively small leaves and rugose monocarps. Unique in the genus by its basally connate petals.

Grupo Pedra do Cavalo 747 (CEPEC, U).

7. Hornschuchia myrtillus Nees von Esenbeck, Flora 4: 302. 1821.

Bahia (Ilhéus, Itamaraju, Prado, Santo Antônio de Jesus), Espírito Santo (Linhares). At sea level. Forest.

Generally cauliflorous shrub or treelet, 0.5-2.5 m tall; leaves elliptic to rhombic or narrowly so, $3-12 \times 1.5-5 \mathrm{~cm}$, primary vein flat to slightly impressed on the upper side; flowers in sometimes flagelliform inflorescences, white; monocarps 1-2, 14-20 x 5 mm, seeds 1-2.

Kallunki \& Pirani 465 (CEPEC, NY, OWU, SPF).

8.Hornschuchia obliqua Maas \& van Setten, Proc. Kon. Nederl. Akad. Wetensch. C 91: 260. f. 18 \& 19. 1988.

Bahia (Cairu, Uruçuca). At sea level. Forest.

Tree, 6-8 m tall; leaves elliptic, 19-38 x $10-17 \mathrm{~cm}$, primary vein flat or slightly impressed on the upper side; flowers in inflorescences, white; monocarps 1-2, 12-23 x 5-8 mm, seeds 1-2.

Very typical by its definitively asymmetrical leaf base and a terminal, many-flowered inflorescence.

Amorim et al. 794 (CEPEC, U).

9. Hornschuchia polyantha Maas, Proc. Kon. Nederl. Akad. Wetensch. C 89: 258. f. 7. 1986.

Bahia (Aurelino Leal, Camacã, Itapebi, Ubaitaba, Una). At sea level. Forest.

Flagelliflorous shrub, 2-4 m tall; leaves narrowly elliptic, $10-20 \times 3-7 \mathrm{~cm}$, primary vein flat or slightly raised on the upper side; flowers in flagelliform inflorescences, white; monocarps 1-3, $35 \times 7 \mathrm{~mm}$, seeds unknown.

Resembling $H$. bryotrophe in its flagelliform inflorescence, but leaves very different with regular base.

Amorim et al. 827 (CEPEC, NY, U).

10. Hornschuchia santosii D.M. Johnson, Brittonia 47: 303. f. 24A-E. 1995.

Bahia (Buerarema, Canavieiras, Teixeira de Freitas). At sea level. Forest.

Shrub or treelet, 2-7 $\mathrm{m}$ tall; leaves elliptic to obovate or narrowly so, $10-29 \times 4-8 \mathrm{~cm}$, primary vein impressed on the upper side; flowers in inflorescences, white; stamens 6 to 18 ; carpels 2 to 9 , monocarps $1,20 \times 12 \mathrm{~mm}$, seeds 6 .

According to Johnson characterized by distinctly raised secondary and tertiary venation.

Carvalho et al. 1172 (CEPEC, NY, U).

\section{Malmea R.E. Fries}

Leaves with impressed primary vein on the upper side; indument of simple hairs; bracts 2 per flower; flowers in 1-4-flowered, leafopposed inflorescences, sepals free, petals free; fruit apocarpous, monocarps many, indehiscent, 1-seeded.

Chatrou, L.W. 1998. Changing Genera. Systematic studies in Neotropical and West African Annonaceae. Pp. 144-155.

1. Malmea obovata R.E. Fries, Ark. Bot. 5(4): 7. t. 1, f. 7-12. 1905.

Bahia (Ilhéus). At low elevation. Forest.

Woody plant, of unknown height; leaves narrowly elliptic to elliptic, or narrowly obovate to obovate, $15-17 \times 5-6 \mathrm{~cm}$, sparsely hairy on the lower side; flower colour unknown (black in sicco); monocarp scars ca. 40, but shape, size, and number of monocarps and seeds not observed.

Only once collected.

Riedel 525 (holotype, S; isotype, LE).

XIII. Oxandra A. Richard (by L. Junikka)

Leaves with raised or impressed primary vein on the upper side; indument of simple 
hairs; bracts several per flower; flowers solitary or in few(1-2)-flowered inflorescences, axillary, sepals free, petals free, white; fruit apocarpous, monocarps 1-9, indehiscent, 1-seeded.

Fries, R.E. 1931. Revision der Arten einiger Anonaceen-Gattungen II. Acta Horti Berg. 10(2): 318-322.

1. Oxandra martiana (Schlechtendal) R.E. Fries, Acta Horti Berg. 10(2): 165. f. 4. d \& e. 1931.

Espírito Santo (Conceição do Castelo), Minas Gerais (Caratinga, Lagoa Santa, Lima Duarte, Guidoval, Marliéria), Rio de Janeiro (Cachoeiras de Macacu, Petrópolis). To 800 m. Forest.

Tree, up to $20 \mathrm{~m}$ tall; leaves narrowly elliptic, 8-13 x 2-3.5 cm, primary vein impressed on the upper side; flowers white; monocarps 4-9, ellipsoid, 12 x $15 \mathrm{~mm}$.

This species is distinct by its narrow, not shiny, elliptic leaves, with less reticulate venation compared with $O$. reticulata, and by short pedicels.

Lopes \& Andrade 840 (SPF, U).

2. Oxandra nitida R.E. Fries, Acta Horti Berg. 10(2): 160. f. 4c. 1931.

Bahia (Itabuna), Espírito Santo (Colatina, Guarapari, Linhares), Rio de Janeiro (Nova Friburgo, Petrópolis, Rio de Janeiro, Saquarema). At sea level. Forest.

Tree, up to $20 \mathrm{~m}$ tall; leaves narrowly obovate (or elliptic), 5-8 x 1.5-2 cm, primary vein raised on the upper side; flowers white; monocarps ellipsoid, 13 × $10 \mathrm{~mm}$, number unknown.

This species can be recognized by its narrowly obovate leaves (in mature trees, in saplings elliptic), which are shiny on the upper side.

Maas et al. 8840 (RB, SPF, U).

3. Oxandra reticulata Maas, Proc. Kon. Nederl. Akad. Wetensch. C 89: 261. f. 9, 10b, 11a-d. 1986.
Minas Gerais (Montes Claros, Pedra Azul), Tocantins (Araguaína). To $300 \mathrm{~m}$. Forest.

Tree or shrub, 0.8-12 $\mathrm{m}$ tall; leaves elliptic to narrowly ovate, $5-10 \times 2-4.5 \mathrm{~cm}$, glabrous, minutely reddish black dotted, primary vein raised on the upper side; flowers white; monocarps 1-4, broadly ellipsoid, 13-19 x 11-14 mm.

This species is characterized by a strongly reticulate tertiary venation.

Irwin et al. 21255 (NY).

\section{Oxandra sp. 1}

Bahia (Boquira, Caetité, Campo Formoso, Delfino, Gentio do Ouro, Oliveira dos Brejinhos). To $1000 \mathrm{~m}$. Forest, cerrado.

Tree or shrub, up to $7 \mathrm{~m}$ tall.

The specimens studied are different from $O$. reticulata by conspicuously hairy flower buds, thickened and almost woody fruiting pedicels, and by somewhat differently shaped monocarps. It may prove to represent an undescribed species.

Harley et al. 16751 (CEPEC, K, L, U).

\section{Oxandra sp. 2}

Espírito Santo (Linhares). At sea level. Forest.

Tree, up to $25 \mathrm{~m}$ tall; leaves narrowly elliptic, 5-7.5 x 2-3 cm, glabrous, minutely reddish black dotted, primary vein raised on the upper side; flower buds greenish; monocarps 1-5, ellipsoid, 17-18 x 12-13 mm.

The only specimen is different from $C$. reticulata by narrowly elliptic, shiny leaves with acute base, and by very long pedicels. It is possibly undescribed.

Local name: Imbiú-preto.

Folli et al. 545 (CVRD, MO, U).

\section{Oxandra sp. 3}

Bahia (Rodovia Barreiras-Ibotirama). At 600-800 m. Low forest.

Shrub, $1 \mathrm{~m}$ tall; leaves narrowly elliptic to narrowly ovate, $3.5-5 \times 1.5-2 \mathrm{~cm}$, lower side covered with short and long hairs, primary vein 
flat or slightly impressed on the upper side; monocarps 3-5, ellipsoid to ovoid, 10-11 x 6 $\mathrm{mm}$.

The only specimen studied resembles $O$. sessiliflora R.E. Fries, but in that species the primary vein is mostly slightly raised.

Pereira et al. 1600 (U).

\section{Porcelia Ruiz \& Pavón}

Leaves asymmetrical, with raised primary vein on the upper side; indument of simple hairs; bracts absent; inflorescences severalflowered, terminal on short shoots bearing 2-5 small leaves, sepals free, petals free, yellow to cream; fruit apocarpous, monocarps 2-3, indehiscent, large, woody, few- to manyseeded.

Murray, N.A. 1993. Revision of Cymbopetalum and Porcelia (Annonaceae).

Syst. Bot. Monogr. 40: 89-121.

1. Porcelia macrocarpa (Warming) R.E. Fries, Acta Horti Berg. 10(1): 31. f. 4c \& d. 1930.

Bahia (Ilhéus), Minas Gerais (Paraopeba, Sete Lagoas, Uberaba), Rio de Janeiro (Cabo Frio), São Paulo (Botucatu, Campo Alto, Espírito Santo do Pinhal, Iguape, Itatinga, Piracicaba, Presidente Venceslau, São Paulo). To $400 \mathrm{~m}$. Forest.

Tree, 5-25 $\mathrm{m}$ tall; leaves narrowly elliptic to narrowly ovate, $7-15 \times 2-3 \mathrm{~cm}$; monocarps 20-90 x 30-40 mm, seeds 3-17.

Lima et al. $5187(\mathrm{U})$.

\section{Pseudoxandra R.E. Fries}

Leaves with raised primary vein on the upper side, a distinct marginal vein present, almost touching the margin; indument of simple hairs; bracts 2 per flower; flowers solitary, axillary, often produced at the main trunk, sepals basally connate, petals free, green to cream; fruit apocarpous, monocarps 1-15, indehiscent, 1-seeded.
Fries, R.E. 1937. Revision der Arten einiger Anonaceen-Gattungen IV. Acta Horti Berg. 12(2): 222-231.

Maas, P.J.M. \& Westra, L.Y.Th. A preliminar treatment of Pseudoxandra (Annonaceae). In preparation.

1. Pseudoxandra bahiensis Maas, Proc. Kon. Nederl. Akad. Wetensch. C 89: 265. f. 12e \& f, 13. 1986.

Bahia (Belmonte, Camamu, Itacaré, Santa Cruz Cabrália, Una, Uruçuca). At 0900 m. Forest.

Cauliflorous tree, 3-20 m tall; leaves narrowly elliptic, $10-20 \times 2.5-6 \mathrm{~cm}$, verrucose on both sides; flowers cream; monocarps 1-15, wine red maturing black, globose, $15-18 \mathrm{~mm}$ in diam.

Local name: Pindaíba, Pindaíba-preta

Mori et al. 10240 (holotype, CEPEC; isotypes, $\mathrm{G}, \mathrm{K}, \mathrm{MG}, \mathrm{MO}, \mathrm{NY}, \mathrm{RB}, \mathrm{U})$.

\section{Pseudoxandra sp. nov.}

Espírito Santo (Santa Teresa). At 650$800 \mathrm{~m}$. Forest.

Tree, 5-15 $\mathrm{m}$ tall; leaves narrowly elliptic to narrowly elliptic, 7-15 x 3-6 cm, shiny and mostly strongly verrucose on the upper side; flowers green to yellow; monocarps 1-15, globose, reddish or brownish green to orange, 14-25 $\mathrm{mm}$ in diam.

Maas et al. 8833 (AAU, B, F, GB, K, LZ, MBML, MO, NY, P, U, US, WIS, WU).

XVI. Rollinia A.F.C.P. de Saint-Hilaire

Leaves with impressed primary vein on the upper side; indument of simple (furcate to stellate) hairs; bracts 2 per flower; flowers propellor-like, solitary or in several-flowered inflorescences, supra-axillary or leaf-opposed, occasionally sub-axillary, sepals generally free, petals connate, cream to yellow, rarely red, outer ones winged; fruit syncarpous, manyseeded, indehiscent, composed of 1-170 carpels, or rarely fruit apocarpous, composed of few to many indehiscent and 1-seeded monocarps. 
Maas, P.J.M. \& Westra, L.Y.Th. 1992. Rollinia. Flora Neotropica Monograph 57: 1-188.

1. Rollinia bahiensis Maas \& Westra, Proc. Kon. Nederl. Akad. Wetensch. C 92: 299. f. 3 \& 4. 1989.

Bahia (Água Preta, Itacaré, Jaobina, Santa Cruz Cabrália, Una, Uruçuca). To 600 m. Forest.

Tree, to $8 \mathrm{~m}$ tall; leaves narrowly elliptic to elliptic, $9-18$ x $3-7.5 \mathrm{~cm}$, with erect (to rarely appressed), straight to somewhat crisped, simple hairs on the lower side; flowers cream to yellow, wings 4-5 mm long; fruit syncarpous, 25-30 x 30-35 mm, carpels 30-50.

Typical by coriaceous leaves with an indument of brown, erect hairs on the lower side.

Mori et al. 10315 (CEPEC, U).

2. Rollinia dolabripetala (Raddi) R.E. Fries, Kongl. Svenska Vetenskapsakad. Handl. n.s. 34(5): 45. 1900.

Minas Gerais (Caratinga, Diamantina, Lagoa Santa, Santana do Riacho), Rio de Janeiro (Casemiro de Abreu, Itatiaia, Nova Iguaçu, Rio de Janeiro), São Paulo (Santos-Sorocaba). To $1450 \mathrm{~m}$. Forest.

Tree, 8(-20) $\mathrm{m}$ tall; leaves narrowly ovate to narrowly elliptic, $6-17 \times 1.5-4.5 \mathrm{~cm}$, covered with erect, simple (to furcate) hairs on the lower side; flowers green to yellow with brownish indument, wings $8-13 \mathrm{~mm}$ long; fruit syncarpous, yellow, $15-30$ x 20-30 mm, carpels 50-100.

Typical by comparatively narrow, brown leaves; flowers with almost horizontal wings.

Angeli et al. 500 (AAU, GUA, K, U).

3. Rollinia emarginata Schlechtendal, Linnaea 9: 318. 1835.

Bahia (Brumado, Igaporã, Ilhéus, Itabuna), Minas Gerais (Gonçalves, Liberdade, Lima Duarte, Pedro Leopoldo), Rio de Janeiro (Itatiaia, Nova Friburgo, Maricá), São Paulo (Campos do Jordão, Cássia dos Coqueiros, Iporanga, Itapeva, Jundiaí, Paraguaçu, Paulista,
São Manoel, São Paulo). To 1000 m. Forest.

Tree or shrub, 1-20 m tall; leaves narrowly elliptic, ovate, obovate or circular, 1-14 x 1-9 cm, sparsely covered with appressed hairs on the lower side; flowers green to yellow, wings 5-18 mm long; fruit syncarpous, yellow, 10-40 x 10-40 mm, carpels 15-50.

Maas \& Westra (1992) prefer to treat $R$. emarginata as one highly variable species. However, Záchia and Irgang (1996) preferred to split it in several species. According to them 3 species are found in C-E Brazil: $R$. emarginata Schlechtendal proper, $R$. rugulosa Schlechtendal, and $R$. salicifolia Schlechtendal. They separate these species using mainly fruit and leaf characters.

Maas et al. 6979 (CEPEC, K, NY, U).

4. Rollinia exsucca (A.P. de Candolle ex Dunal) A.L.P.P. de Candolle, Mem. Soc. Phys. Genève 5: 199. pl. 2, f. A. 1832.

Minas Gerais (Viçosa). To 900 m. Forest.

Tree or shrub, 2-35 $\mathrm{m}$ tall; leaves elliptic to ovate, $8-20 \times 3-8 \mathrm{~cm}$, rather densely covered with appressed hairs and glaucous on the lower side; flowers green to yellow with reddish inner base, wings 6-15 mm long; fruit syncarpous, yellow, 1-2.5 x 1-2.5 mm, carpels 30-50.

Typical by bicolorous, mostly coriaceous leaves often with obscure venation and silky hairs on the lower side.

Alvim 376 (G).

5. Rollinia ferruginea (R.E. Fries) Maas \& Westra, Proc. Kon. Nederl. Akad. Wetensch. C 92: 301. 1989.

Rio de Janeiro (Rio de Janeiro). To 700 m. Forest.

Treelet, $2 \mathrm{~m}$ tall; leaves narrowly elliptic to ovate, $8-15 \times 4-8 \mathrm{~cm}$, densely covered with brown, erect hairs on the lower side; flower colour unknown, wings $3 \mathrm{~mm}$ long; fruit apocarpous, colour unknown, 10-12 x 5-6 mm, carpels 10 .

Close to $R$. parviflora but distinctive by its much longer hairs and larger leaf size.

Sucre 7643 (RB). 
6. Rollinia laurifolia Schlechtendal, Linnaea 9: 319. 1835.

Bahia (Ilhéus, Itabuna, Itapebi, Santa Cruz Cabrália, Uruçuca), Espírito Santo (Goitacazes, Linhares, Vargem Alta-São José de Fruteira), Minas Gerais (Belo Horizonte, Bom Sucesso, Caparaó, Carangola, Caratinga, Diamantina, Marliéria, Miraí, Nova Ponte, Rio Vermelho, Santa Bárbara, Santana do Riacho, Santos Dumont), Rio de Janeiro (Nova Friburgo, Petrópolis, Sumidouro, Teresópolis), São Paulo (Cananéia, Iguape, Moji das Cruzes). To $750 \mathrm{~m}$. Forest.

Tree or shrub, to $25 \mathrm{~m}$ tall; leaves narrowly elliptic, 9-18 x 3-6.5 cm, rather densely covered with appressed hairs on the lower side and also often on the upper side (!); flowers green to yellow, inner base purplish, wings 8-14 mm long; fruit syncarpous, black, 15-25 x 15-20 $\mathrm{mm}$, carpels 50-100.

Close to $R$. sericea (cf. amount of carpels), but leaves of $R$. laurifolia are nearly always distinctly hairy on the upper side.

Folli 43 (CVRD, U).

7. Rollinia leptopetala R.E. Fries, Kongl. Svenska Vetenskapsakad Handl. n.s. 34(5): 50. t. 7 , f. 3 \& 4. 1900.

Bahia (Barreiras, Boa Vista do Tupim, Boquira, Caetité, Encruzilhada, Gentio do Ouro, Iaçu, Itiúba, Machado, Morro do Chapéu, Mucujê, Oliveira dos Brejinhos, Paramirim, Tremedal, Uibaí), Minas Gerais (Espinosa, Itaobim, Januária, Monte Azul). To 1000 m. Mostly in caatinga. A collection assigned to Rio de Janeiro (Glaziou 10231) is of doubtful provenance.

Tree or shrub, 2-9 $\mathrm{m}$ tall; leaves elliptic to ovate, 4-7 x 1.5-3 cm, rather densely covered with appressed to semi-erect hairs on the lower side; flowers red, wings 7-12 mm long; fruit apocarpous, yellow, orange, or red, 8-13 x 4-6 mm, carpels 15-20.

The red flower colour of this species is unique in the genus.

Anderson et al. 36947 (K, U).
8. Rollinia mucosa (Jacquin) Baillon, Adansonia 8: 268. 1868.

Bahia (Ilhéus, Ipiaú, Itabuna, Itacaré), Espírito Santo (Cachoeiro do Itapemirim, Marilândia), Minas Gerais (Carangola, Caratinga, Manhuaçu, Virgem da Lapa), Rio de Janeiro (Parati, Rio de Janeiro), São Paulo (Iporanga, Peruíbe, Rio Claro). To $1500 \mathrm{~m}$. Forest.

Tree, to $20 \mathrm{~m}$ tall; leaves narrowly elliptic $10-25 \times 4-8.5 \mathrm{~cm}$, rather densely covered with appressed hairs on the lower side; flowers yellow, wings 7-15 mm long; fruit syncarpous, yellow to brown, 20-120 x 25-110 mm, carpels 50-150.

Characterized by appressed hairs on the lower side, sepals lacking gibbosities, and the often large, spiny fruit. This species is often cultivated because of its edible fruit.

\section{Hage \& Brito 676 (CEPEC, U).}

9 Rollinia parviflora A.F.C.P. de Saint-Hilaire, Fl. Bras. merid. 1: 30. 1825.

Rio de Janeiro (Maricá, Niterói, Parati, Rio de Janeiro). To 1000 m. Forest.

Small tree or shrub, 1-6 m tall; leaves elliptic to ovate, $4-8 \times 1-4 \mathrm{~cm}$, densely covered with erect hairs on the lower side; flowers white to yellow, wings 2-3 mm long; fruit apocarpous, yellow-orange to orange, 7-12 x 4-6 mm, carpels 1-6.

This species is typical by its erect, ferruginous hairs on most parts of the plant, and by its apocarpous fruit.

Maas et al. 7089 (GUA, K, MO, NY, U, WIS, WU, Z).

10. Rollinia sericea (R.E. Fries) R.E. Fries, Acta Horti Berg. 12(1): 152. 1934.

São Paulo (Bertioga, Campinas, Cananéia, Caraguatatuba, Eldorado, Iguape, Iporanga, Miracatu, Santo André, São Miguel Arcanjo, São Paulo, São Roque, São Sebastião, Sete Barras, Sorocaba, Subaúma, Tapiraí, Ubatuba). To $550 \mathrm{~m}$. Forest.

Tree, 3-15(-26) $\mathrm{m}$ tall; leaves elliptic to narrowly elliptic, 5-16 x 2-5.5 cm, densely 
covered with appressed hairs on the lower side; flowers cream to yellow, wings $9-16 \mathrm{~mm}$ long; fruit syncarpous, yellow, 20-30 x 20-25 $\mathrm{mm}$, carpels 100-150.

Differing from $R$. laurifolia by its leaves which are glabrous on the upper side and by its fruit composed of $>100$ carpels.

Mosén 2769 (S).

11 Rollinia sylvatica (A.F.C.P. de Saint-Hilaire) Martius in Martius, Fl. bras. 13(1): 18. 1841.

Bahia (Abaíra, Caetité, Estiva, Maracás, Morro do Chapeu, Mucujê, Piatã, Rio de Contas, Souto Soares), Espírito Santo (Estrada de Nanuque, Santo Amaro), Minas Gerais (Aimorés, Belo Horizonte, Caparaó, Carangola, Caratinga, Guarani, Lagoa Santa, Pedra Azul, Perdizes, Santana do Riacho, São Tomé das Letras), Rio de Janeiro (Itatiaia, Nova Friburgo, Petrópolis, Rio de Janeiro), São Paulo (Águas de Lindóia, Bananal, Barra do Turvo, Caconde, Campinas, Cardoso, Corumbataí, Eldorado, Espírito Santo do Pinhal, Guapiara, Guaratinguetá, Ipeúna, Itapira, Joanópolis, Moji das Cruzes, Paraguaçu, Paulista, Piracicaba, Santo Antônio de Posse, São Miguel Arcanjo, São Paulo, Sorocaba, Vinhedo). To $1000 \mathrm{~m}$. Forest.

Tree or shrub, to $10 \mathrm{~m}$ tall; leaves elliptic to narrowly elliptic, $4-17 \times 1.5-8 \mathrm{~cm}$, densely covered with erect hairs on the lower side; flowers green to yellow, wings 5-12 mm long; fruit syncarpous, bright yellow-orange, 25-30 x 30-50 mm, carpels 30-50.

Harley et al. 16512 (CEPEC, K, M, MO, NY, P, RB, U, US).

12. Rollinia ubatubensis Maas \& Westra, Proc. Kon. Nederl. Akad. Wetensch. C 92: 313. f. 14 \& 14. 1989.

São Paulo (Ubatuba). To $850 \mathrm{~m}$. Forest.

Tree, 3-20 m tall; leaves elliptic to narrowly elliptic, $8-22$ x 3-8 cm, rather densely covered with erect hairs on the lower side; flowers yellow-ferruginous, wings $12-16 \mathrm{~mm}$ long; fruit syncarpous, green, 35-40 x 25$35 \mathrm{~mm}$, carpels 120-170.

Differing from $R$. dolabripetala by a denser, almost velutinous leaf indument and by longer, thicker pedicels. It lacks stellate hairs and has more numerous, smaller carpels than $R$. sylvatica (120-170 versus $30-50)$.

Gentry \& Zardini 49356 (U).

13. Rollinia xylopiifolia (A.F.C.P. de Saint-Hilaire \& Tulasne) R.E. Fries, Acta Horti Berg. 10(2): 315. 1931.

Espírito Santo (Cachoeiro do Itaperimim - Vargem Alta), Rio de Janeiro (Nova Friburgo, Petrópolis, Rio de Janeiro), São Paulo (Santo André). To $650 \mathrm{~m}$. Forest.

Small tree or shrub, to $2 \mathrm{~m}$ tall; leaves narrowly elliptic to narrowly elliptic-ovate, 5-10 $x$ 1-2.5 cm, rather densely covered with appressed hairs on the lower side; flowers cream, wings 3-5 mm long; fruit syncarpous, blackish when dry, 10-20 x 15-18 mm, carpels 15-30.

Its dark Xylopia-like leaves with revolute margins and a hairy primary vein on the upper side distinguish $R$. xylopiifolia from $R$. emarginata. The fruit of both species look very similar.

Brade 19766 (RB, U).

\section{Trigynaea Schlechtendal}

Leaves more or less triplinerved at the base, with primary vein impressed to slightly raised on the upper side; indument of simple hairs; bracts absent; flowers solitary or in inflorescences, internodal or supra-axillary, rarely axillary, sepals basally connate into a cupshaped calyx, petals free, yellow to white; fruit apocarpous, monocarps 1-9, indehiscent, several-seeded.

Johnson, D.M. \& Murray, N.A. 1995. Synopsis of the tribe Bocageeae (Annonaceae) with revisions of Cardiopetalum, Froesiodendron, Trigynaea, Bocagea, and Hornschuchia. Brittonia 47(3): 248-319. 
1. Trigynaea axilliflora D.M. Johnson \& N.A. Murray, Brittonia 47: 289. f. 15A-E. 1995.

Rio de Janeiro (Rio de Janeiro). At ca. $500 \mathrm{~m}$. Forest on coarse sand.

Tree, 2.5-20 m tall; leaves narrowly elliptic, 11-12 x 3-4 cm, primary vein slightly impressed on the upper side; flowers white with a sweet scent; monocarp 1, 35-40 x 37-38 $\mathrm{mm}$, seeds $>4$.

Unique in the genus by axillary flowers, morphologically also close to $T$. duckei.

Maas et al. 8817 (H, RB, SPF, U).

2. Trigynaea oblongifolia Schlechtendal, Linnaea 9: 329. 1835.

Minas Gerais (Carangola), Rio de Janeiro (Magé, Parati), São Paulo (Cubatão). At 600-1200 m. Forest.

Shrub or tree, 3-4 m tall; leaves narrowly oblong-elliptic, 10-20 x 4-6 cm, primary vein impressed to slightly raised on the upper side, young leaves densely covered with appressed hairs on the lower side; flowers yellow to cream; number of carpels 3-9, monocarps obovoid, number unknown, 30-35 x $25 \mathrm{~mm}$, densely hairy, seed number unknown.

Close to T. axilliflora, but flowers not axillary and a denser indument.

Hoehne 7974 (NY, S).

\section{Unonopsis R.E. Fries}

Leaves with primary vein raised on the upper side; indument of simple hairs; bracts 2 per flower; flowers solitary or in few- to manyflowered inflorescences, axillary, sepals connate, petals free, green, cream, yellow, or orange; fruit apocarpous, monocarps 6-25, indehiscent, 1(-2)-seeded, seeds pitted.

Fries, R.E. 1931. Revision der Arten einiger Anonaceen-Gattungen IV. Acta Horti Berg. 12(2): 231-264.

1. Unonopsis lindmanii R.E. Fries, Kongl. Svenska Vetenskapsakad. Handl. n.s. 34(5): 27. t. 4, f. 3-8. 1900.
Goiás (Cachoeira Alta, Caldas Novas, Colinas do Sul, Corumbaíba, Goiânia, Ipameri, Niquelândia, São Miguel do Araguaia, Uruaçu), Minas Gerais (Conquista, Indianópolis, Paracatu, Uberlândia), São Paulo (Andradina, Castilho, Dracena, Ilha Solteira, Paulo de Faria, Pindorama, Presidente Epitácio, Riolândia, Teodoro Sampaio). To $800 \mathrm{~m}$. Forest, often along rivers.

Tree, 3-18 m tall; leaves narrowly elliptic, $16-20 \times 5-6 \mathrm{~cm}$, rather densely to densely covered with erect hairs on the lower side; inflorescences few-flowered, flowers green to white; monocarps 6-8, yellowish to purple, 9-22 x 9-10 mm, seeds 1-2.

Typical of this species is the indument of erect hairs on young branches and on the lower side of the lamina.

Local name: Envira-preta, Pindaíba.

Pirani et al. 2081 (NY, SPF, U).

2. Unonopsis riedeliana R.E. Fries, Ark. Bot. 5(4): 11. t. 2, f. 1-6. 1906.

Rio de Janeiro (Petrópolis). Forest.

Tree, 6-8 $\mathrm{m}$ tall; leaves slightly asymmetrical, narrowly elliptic, $8-13$ x 1.5-2.5 $\mathrm{cm}$, sparsely covered with appressed hairs on the lower side; inflorescences many-flowered, pedicels 10-18 mm long, petals 8-10 mm long; fruit unknown.

Only known from the type. Very typical by its very narrow leaves.

Riedel s.n. [Oct 1823] (holotype, S; isotypes, $\mathrm{K}, \mathrm{LE}$ ).

\section{Unonopsis sp. nov. 1}

Bahia (Belmonte, Cairu, Canavieiras, Ilhéus, Itamaraju-Prado, Olivença, Porto Seguro, Prado, Santa Cruz Cabrália, Una, Uruçuca, Valença). From sea level to $80 \mathrm{~m}$. Muçununga forest.

Tree or shrub, 3-25 m tall; leaves narrowly elliptic to narrowly obovate, $10-25 \mathrm{x}$ 2.5-4(-9) cm, sparsely to rather densely covered with appressed hairs on the lower side; inflorescences 1-few-flowered; flowers 
cream to orange; monocarps 7-35, orange to red when ripe, 10-21 x 9-16 mm, seed 1 .

Local name: Pindaíba, Pindaíba-preta, Pindaíba-da-muçununga, Tortuguero.

This is one of the few orange-flowered species of Unonopsis.

Maas et al. 8825 (CVRD, U).

\section{Unonopsis sp. nov. 2}

Espírito Santo (Linhares). At sea level. Forest.

Tree, $18 \mathrm{~m}$ tall; leaves narrowly elliptic to narrowly obovate, $17-23 \times 5-7.5 \mathrm{~cm}$, subglabrous on the lower side; inflorescences several-flowered; flower buds greenish; fruit solitary, monocarps ca. 6 , brownish green, 19 x $20 \mathrm{~mm}$, very densely covered with brown wooly hairs, seed 1 .

Local name: Pindaíba.

Sucre 8355 (RB, U).

\section{Unonopsis sp. nov. 3}

Espírito Santo (Santa Teresa). At 700$800 \mathrm{~m}$. Forest on brown sand.

Tree, 4-10 m tall; leaves (narrowly) elliptic, $14-25 \times 5.5-9 \mathrm{~cm}$, sparsely covered with appressed hairs on the lower side; flowers solitary, cream to yellow; fruit unknown.

Maas et al. 8831 (MBML, U).

\section{Unonopsis sp. nov. 4}

Espírito Santo (Linhares). At sea level. Margin of Muçununga forest, on white sand.

Shrub or tree, 3-4 m tall; leaves narrowly elliptic, 9-22 x 3.5-6 cm, subglabrous on the lower side; inflorescences several-flowered; flowers orange; young monocarps green, 10$13 \mathrm{~mm}$ in diam., glabrous, seed 1.

Maas et al. 8825 (CVRD, U).

XIX. Xylopia Linnaeus

Leaves with impressed primary vein on the upper side; indument of simple hairs; bracts 2 per flower; flowers solitary, axillary, sepals connate, petals free, often unequal, cream to yellow, rarely red; fruit apocarpous, monocarps many, dehiscent, several-seeded, seeds arillate.
Dias, M.C. 1988. Estudos taxonômicos do gênero Xylopia L. (Annonaceae) no Brasil extra-amazônico. Dissertação de Mestrado. Universidade Estadual de Campinas. Pp 1-183. Fries, R.E. 1930. Revision der Arten einiger Anonaceen-Gattungen I. Acta Horti Berg. 10(1): 86-126.

1. Xylopia aromatica (Lamarck) Martius, Fl. bras. 13(1): 43. 1841.

Bahia (Alagoinhas, Aramari, Barreiras, Candeias, Correntina, Dias d'Ávila, Nazaré das Farinhas), Distrito Federal (Brasília), Goiás (Alto Paraíso de Goiás, Barro Alto, Caldas Novas, Chapada do Guimarães, Curumbaíba, Ipameri, Itarumã, Jataí, Minaçu, Niquelândia, São João da Aliança, Taguatinga, Uruaçu), Minas Gerais (Belo Horizonte, Curvelo, Diamantina, Divinópolis, Jaboticatubas, Joaquim Felício, Lagoa Santa, Marliéria, Paraopeba, Santana do Riacho, Sacramento, Uberlândia, Unaí), São Paulo (Andradina, Araraquara, Assis, Barretos, Bauru, Botacatu, Brotas, Cajuru, Casa Branca, Cosmorama, Descalvado, Estreito, Igarapava, Ipeúna, Itirapina, José Bonifácio, Moji-Guaçu, MojiMirim, Monteiro Lobato, Monte Mor, Nova Aliança, Novo Horizonte, Paraguaçu Paulista, Paulo de Faria, Pedregulho, Penápolis, Pindorama, Piraçununga, Platina, Ribeirão Preto, Sales, Santa Rita do Passa Quatro, Votuporanga), Tocantins (Paraíso do Tocantins, Pequizeiro). Frequently in cerrado on sandy soils.

Tree, 2-15 m tall; leaves narrowly ovate, 9-13 x 3-4 cm, densely covered with erect hairs on the lower side; flowers white; monocarps 20-40, constricted (in sicco), 25-35 mm long, seeds ca. 6, bluish.

The most common Annonacea in the Neotropics!

Harley 21849 (K, SPF, U).

2. Xylopia brasiliensis Sprengel, Neue Entd. 3: 50.1822.

Minas Gerais (Caldas, Coronel Pacheco, Jequeri, Três Marias), Rio de Janeiro (Nova 
Friburgo, Parati, Teresópolis), São Paulo (Amparo, Angatuba, Anhembi, Cajuru, Campinas, Cubatão, Ibiúna, Iguape, Jacareí, Miracatu, Pariquera-Açu, Pirapora do Bom Jesus, Queluz, Santos, São Paulo, Sete Barras, Ubatuba). Forest.

Tree, 15-20 m tall, bark scaly and reddish, crown regular, pyramidal; leaves very narrowly ovate, $6-8 \times 0.8-1.3 \mathrm{~cm}$, sparsely covered with erect hairs on the lower side, soon glabrous; flowers reddish; monocarps 5-10, 23-30 mm long, constricted, seeds 3 .

Nadruz et al. 526 (RB, SPF).

3. Xylopia emarginata Martius in Martius, Fl. bras. 13(1): 42. 1841.

Bahia (no exact locality), Goiás (Aragarças, Caldas Novas, Jataí, Minaçu), Minas Gerais (Alpinópolis, Belo Horizonte, Diamantina, Joaquim Felício, Santana do Riacho), Rio de Janeiro (no exact locality), São Paulo (Brotas, Conchal, São Simão). Forest and gallery forest in savanna areas.

Tree, 8-15 m tall; leaves narrowly ovate to narrowly elliptic, $3-5 \mathrm{x}$ ca. $1-1.5 \mathrm{~cm}$, sparsely covered with appressed hairs on the lower side; flowers cream, yellow or orange; monocarps 5-10, not constricted, $25-30 \mathrm{~mm}$ long, seeds 4-5.

This species is typical by its small, rounded to emarginate leaves.

Kuhlmann 5003 (SP, US).

4. Xylopia frutescens Aublet, Hist. Pl. Guiane 1: 602. t. 242. 1775.

Bahia (Cachoeira, Canavieiras, Muritiba, Porto Seguro, Valença), Espírito Santo (Linhares), Goiás (Ribeirão Corda), Minas Gerais (Formiga, Patrocínio), Rio de Janeiro (Santa Maria Madalena, São Gonçalo). At sea level to $1200 \mathrm{~m}$. Forest.

Tree or shrub, 4-6 m tall; leaves narrowly elliptic to narrowly ovate, $5-6 \times 1-1.5 \mathrm{~cm}$, densely to sparsely covered with appressed hairs; flowers cream or white; monocarps 310, not constricted, 19-21 mm long, seeds 2-3. Santos 2818 (CEPEC).
5. Xylopia involucrata M.C. Dias \& Kinoshita, Kew Bull. 53(2): 471. f. 1. 1998.

Bahia (Belmonte, Canavieiras, Ilhéus, Maraú, Una). At sea level. Forest.

Tree, 3-9 m tall; leaves ovate, 13-15 x $5-8 \mathrm{~cm}$, densely covered with erect, ferruginous hairs on the lower side; flowers greenish; monocarps ca. 25 , constricted, $20-25 \mathrm{~mm}$ long, seeds $2-3$.

This species is very typical by its large involucrate bracts and large leaves.

Mori \& Benton 13248 (CEPEC, NY, U).

6. Xylopia laevigata (Martius) R.E. Fries, Kongl. Svenska Vetenskapsakad. Handl. n.s. 34(5): 37. t. 6, f. 1. 1900.

Bahia (Abaíra, Belmonte, Canavieiras, Esplanada, Jandaíra, Lençóis, Morro do Chapéu, Porto Seguro, Salvador, Valença), Espírito Santo (Cachoeiro do Itapemirim, Guarapari, Linhares, São Mateus, Vila Velha), Minas Gerais (Tombos), Rio de Janeiro (Itatiaia, Petrópolis, Resende, Rio de Janeiro). Forest.

Tree or shrub, 2-15 m tall; leaves narrowly elliptic to narrowly ovate, $6-8$ x 2-2.5 $\mathrm{cm}$, subglabrous on the lower side; flowers greenish; monocarps 5-15, constricted, 27-29 mm long, seeds 2-5.

The leaves of this species resemble much those of certain species of Oxandra.

Souza 196 (CVRD, SPF).

7. Xylopia langsdorffiana A.F.C.P. de Saint-Hilaire \& Tulasne Ann, Sci. Nat., Bot. Sér. 2. 17: 133. 1842.

Xylopia lanceolata R.E. Fries, Kongl. Svenska Vetenskapsakad. Handl. n.s. 34(5): 37. t. 7, f. 1 \& 2.1900.

Rio de Janeiro (Duque de Caxias, Parati, Petrópolis, Rio de Janeiro), São Paulo (Bertioga, Cananéia, Iguape, Pariquera-Açu, Rio Grande, Santos). Forest.

Tree, 5-7 $\mathrm{m}$ tall; leaves narrowly elliptic to narrowly ovate, $10-15 \times 3.5-4.5 \mathrm{~cm}$, sparsely covered with appressed hairs on the lower side, soon glabrous; flower colour unknown; 
monocarps ca. 5, constricted, 25-30 mm long, seeds $4-8$.

Dias (1988) proposed Xylopia langsdorffiana subsp. lanceolata, characterized by narrower leaves but that subspecies is not officially published.

Kirizawa 3226 (SP, SPF).

8. Xylopia ochrantha Martius in Martius, Fl. bras. 13(1): 43. 1841.

Bahia (Belmonte), Espírito Santo (Itapemirim, Linhares), Rio de Janeiro (Macaé, Resende, Rio de Janeiro). Restinga.

Cauliflorous tree or shrub, up to $22 \mathrm{mtall}$; leaves narrowly elliptic, ca. $7 \times 2.5-3.5 \mathrm{~cm}$, sparsely covered with appressed hairs on the lower side, soon glabrous; flowers yellow; monocarps ca. 10, constricted, 30-40 mm long, seeds 4-8.

This species is typical in being cauliflorous (producing flowers at the main trunk), and in having yellowish or brownish hairy flowers and monocarps.

Local name: Coração.

Folli 63 (CVRD, U).

9. Xylopia sericea A.F.C.P. de Saint-Hilaire, Fl. Bras. merid. 1: 41. 1825.

Bahia (Correntina, Ilhéus, Itacaré, Jacobina, Porto Seguro, Santa Cruz Cabrália, Una), Distrito Federal (Brasília), Espírito Santo (Areias, Cássia do Coqueiros, Guarapari, Linhares, Santa Cruz, Santa Teresa, São Mateus, Vila Velha), Goiás (Mambaí), Minas Gerais (Caratinga, Jaboticatubas, Jequeri, Nova Ponte, Patrocínio, Perdizes, Santa Bárbara, Santana de Riacho, São Gonçalo do Rio Abaixo, Varzeão de Minas), Rio de Janeiro (Campos dos Goitacazes, Macaé, Nova Friburgo, Paraíba do Sul, Rio de Janeiro), Tocantins (Formoso do Araguaia). Forest and cerrado.

Tree, 5-29 m tall; leaves narrowly ovate, 8-10 x $1-2.5 \mathrm{~cm}$, densely covered with appressed, silky hairs on the lower side; flowers white to yellow; monocarps 5-10, constricted, 18-25 mm long, seeds 2-4.

Silva et al. 1446 (CEPEC).

\section{Xylopia sp. nov.}

Espírito Santo (Santa Teresa). At $650 \mathrm{~m}$. Forest on brown sand.

Cauliflorous tree, $6 \mathrm{~m}$ tall, with reddish strongly flaking bark; leaves narrowly elliptic to narrowly ovate, $16-20 \times 3-4 \mathrm{~cm}$, sparsely covered with minute appressed hairs on the lower side; flowers not seen; monocarps 1015 , young ones constricted, ca. $10 \mathrm{~mm}$ long, glaucous, seeds 2-3.

Very typical by its strongly flaking bark like in $X$. brasiliensis. It is, however, a cauliflorous tree and it has much larger leaves.

Maas et al. 8834 (MBML, U).

\section{ACKNOWLEDGEMENTS}

The collecting trip of Paul and Hiltje Maas and Leo Junikka (January-February 1999) has been very successful thanks to the help of many persons, among others: Domingos Folli (CVRD), Ludovic Kollmann (MBML), Cyl Farney (RB), and Bruno Kurtz (RB). Thanks are due to an anonymous reviewer for the useful remarks. Renato de Mello-Silva thanks $\mathrm{CNPq}$ for the research fellowship, process 300308/96-5.

\section{REFERENCES}

Berry, P. E. \& Johnson, D. M. 1993. A New Species of Xylopia (Annonaceae) from Southern Venezuela. Novon 3: 99-101. Bridson, G. D. R. \& Smith, E. R. 1991. Botanico-Periodicum-Huntianum/ Supplementum. Pittsburgh, Hunt Institute for Botanical Documentation.

Dias, M. C. 1988. Estudos taxonômicos do gênero Xylopia L. (Annonaceae) no Brasil extra-amazônico. Campinas, Dissertação de mestrado - Universidade Estadual de Campinas, Pp. 1-183.

Dias, M. C. \& Kinoshita, L. S. 1998. A new species of Xylopia L. (Annonaceae) from Bahia, Brazil. Kew Bull. 53(2): 471-474.

Holmgren, P. K., Holmgren, N. H. \& Barnett, L. C. 1990. Index herbariorum, part I: The herbaria of 
the world. $8^{\text {th }}$ ed. New York Botanical Garden.

Jansen-Jacobs, M. J. 1970. New species of Annonaceae from Suriname. Proc. Kon. Nederl. Akad. Wetensch. C 73: 336-342.

Johnson, D. M. \& Mello-Silva, R. 1993. A new species of Hornschuchia (Annonaceae) from atlantic Brazil, with comments on the circumscription of the genus Trigynaea. Contr. Univ. Mich. Herb. 19: 259-263.

Johnson, D. M. \& Murray, N. A. 1990. New species of Guatteria (Annonaceae) from the Guayana Highland. Ann. Missouri Bot. Gard. 77: 598-600.

Kessler, P. J. A. 1993. Annonaceae. Pp. 93129. In: Kubitzki, K. Rohwer, J.G. \& Bittrich, V. (eds.). The families and genera of vascular plants. Vol. 2. Flowering plants. Dicotyledons. Magnoliid, Hamamelid and Caryophyllid families. Berlin. Springer Verlag.

Maas, P. J. M. 1996. Studies in Annonaceae XXX. Monograph of Duguetia: preliminary notes. Bot. Jahrb. Syst. 118: $187-227$.

1999. Studies in Annonaceae

XXXVII. Monograph of Duguetia: preliminary notes II. Bot. Jahrb. Syst. 121: 465-489.

.\& Chatrou, L. W. 1996 (“1995”). Studies in Annonaceaea XXVII. Novelties in neotropical Annonaceae. Feddes Repert. 106: 341-346. , Heusden, E. C. H. Van, KoekNoorman, J., Setten, A. K. Van \& Westra, L. Y. Th. 1986. Studies in Annonaceae VII. New species from the Neotropics and miscellaneous notes.

Proc. Kon. Nederl. Akad. Wetensch. C 89: 249-278. ., Heusden, E. C. H. Van, KoekNoorman, J., Setten, A. K. Van \& Westra, L. Y. Th. 1988. Studies in Annonaceae IX. New species from the
Neotropics and miscellaneous notes. Proc. Kon. Nederl. Akad. Wetensch. C 91: 243-282. ., Koek-Noorman, J., \& Westra, L. Y. Th. 1993. Studies in Annonaceae XVIII. New species from the Neotropics and miscellaneous notes. Bot. Jahrb. Syst. 115: 77-95. .\& Westra, L. Y. Th. 1992. Rollinia. Flora Neotropica Monograph 57: 1-188.

Mello-Silva, R. \& Pirani, J. R. 1988. Guatteria notabilis Mello-Silva \& Pirani, nova espécie de Annonaceae da Cadeia do Espinhaço, Brasil. Bol. Bot. Univ. São Paulo 10: 43-50. $\&$ 1994. Guatteria rupestris (Annonaceae), a new species from Minas Gerais, Brazil. Novon 4(2): 146-150.

\&______. 1999. Annona warmingiana Mello-Silva \& Pirani, a new name for Annona pygmaea (Warm.) Warm. Kew Bull. 54(1): 237238.

Mennega, E. A. 1989. Bibliography of the Annonaceae. Second ed. Vienna, Institute of Botany and Botanical Garden of the University of Vienna. 1993. Bibliography of the Annonaceae. Third ed. Iconography of the Annonaceae. First ed. Vienna. Edited by W. Morawetz. Austrian Academy of Sciences. Research Center for Biosytematics and Ecology, Vienna.

Morawetz, W. \& Maas, P. J. M. 1984. Notes on the systematics of the amazonian genus Guatteriella (Annonaceae). Pl. Syst. Evol. 148: 19-23.

Stafleu, F. A. \& Cowan, R. S. 1976-1988. Taxonomic literature. Vol. 1-7. $2^{\text {nd }} \mathrm{ed}$. Bohn, Scheltema \& Holkema, Utrecht.

Záchia, R. A. 1993. Rollinia maritima Záchia - Uma nova espécie para o gênero Rollinia St.-Hill. (Annonaceae). Bradea 6(28): 242-247. 
\& Irgang, B. E. 1996.

Delimitação de quatro espécies em

Rollinia emarginata Schlecht. sensu lato (Annonaceae). Sellowia 45-48: 73-107.

Zuilen, C. M. van \& Maas, P. J. M. 1994. Studies in Annonaceae XXII. A taxonomic revision of Duguetia A. St.Hil., sections Alcmene and Xylopipetalum. Bot. Jahrb. Syst. 116: 221-242. 